\title{
26. CALCAREOUS NANNOFOSSILS OF THE NORWEGIAN-GREENLAND SEA: ODP LEG 1041
}

\author{
Diane M. Donnally 2,3
}

\begin{abstract}
Ocean Drilling Program Leg 104 recovered sediments containing calcareous nannofossils of latest Oligocene to Holocene age from the Vøring Plateau in the Norwegian-Greenland Sea. The section drilled is virtually the most complete and detailed sedimentary sequence yet obtained from such a high latitude North Atlantic location. Due to unfavorable paleoclimatic conditions, the nannofossil assemblages observed are generally of low diversity and poorly preserved. A limited nannofossil biostratigraphy can still be formulated, although many of the standard low-latitude zonal markers are absent in the area of study.

An important aspect of the Norwegian-Greenland Sea is the response of the sediments to the onset and variability of glaciation in the area. The sediments deposited since the onset of Northern Hemisphere glaciation consist of alternating carbonate- (and nannofossil-) rich interglacial sediments and carbonate-poor glacial sediments. The glacial sediments also contain ice-rafted debris, including reworked Cretaceous and older Cenozoic nannofossils. The reworked nannofossils were most likely deposited by ice-rafting from the area to the south with minor contributions of reworked material from exposed shelf areas near Norway and from fault-exposed outcrops of upthrust Cretaceous rocks in the area.
\end{abstract}

\section{INTRODUCTION}

This study of the calcareous nannofossils found in Leg 104 material focuses on two main topics: the calcareous nannofossil biostratigraphy of the area and the age and possible source of glacial detritus traced by means of redeposited, ice-rafted nannofossils.

The Norwegian-Greenland Sea was cored previously by the Deep Sea Drilling Project (DSDP) Leg 38 in 1974. The calcareous nannofossils from that cruise were studied by Müller (1976). Unfortunately, the sites were only intermittently cored and a complete stratigraphic section was not recovered. Several shallow piston cores have also been obtained by various investigations for studies of the glacial-interglacial fluxes in the region. These cores generally contain sediments representing only the past $0.5 \mathrm{Ma}$ of Norwegian-Greenland Sea history (see discussion and references in Reworked Nannofossils section). DSDP has also occupied sites in the North Atlantic, but that area has different climatic and paleoenvironmental characteristics and thus the nannofossil succession in the Norwegian-Greenland Sea is significantly different.

\section{METHODS AND PROCEDURES}

\section{Preparation}

From the material collected while aboard ship, approximately 1500 samples were selected for this study. Most samples were processed into simple smear slides. Another method of slide preparation was used for the glacial interval samples. These samples contain such a high percentage of ice-rafted debris that the nannofossils are greatly diluted. To eliminate the larger ice-rafted material, thus concentrating the nannofossils, the raw sample was agitated in water and then settled for $1 \mathrm{~min}$. This allowed the coarser glacial debris to settle out of the suspension while most of the calcareous nannofossils remained suspended in the supernatent. Slides were then made from the supernatent. This fast and efficient method removed most of the unwanted larger material.

\footnotetext{
${ }^{1}$ Eldholm, O., Thiede, J., Taylor, E., et al., 1989. Proc. ODP, Sci. Results. 104: College Station, TX (Ocean Drilling Program).

2 AMOCO Production Company, PO Box 50879, New Orleans, LA 70150.

3 Current address: State of Florida, Dept. of Environmental Regulation, 2600 Blair Stone Road, Tallahassee, FL 32399.
}

A JEOL JSM-840 Scanning Electron Microscope (SEM) was used to examine selected samples to identify the minute Pleistocene nannofossils such as Emiliania huxleyi. To concentrate the nannofossils for SEM analysis, the following technique was followed:

1. Approximately $0.5 \mathrm{~g}$ of sediment was stirred in a beaker with approximately $50 \mathrm{~mL}$ of water.

2. The mixture was then agitated for $30 \mathrm{~s}$ in an ultrasonic bath, stirred, then allowed to settle for $1 \mathrm{~min}$.

3. The supernatent was then poured off and allowed to settle. After $1 \mathrm{hr}$, the supernatent was poured off, the residue remaining was diluted, and a drop was dried onto a coverslip to be examined with the SEM.

Another technique was used in this study to compare nannofossils identified under the light microscope with the same specimen seen with the SEM. This method is similar to one used by Applegate and Bergen (pers. commun., 1985). The technique is as follows:

1. A small grid, consisting of 25 sections within $0.8 \mathrm{~cm}^{2}$, was stamped with indelible ink on a coverslip.

2. One drop of the sample solution was dried on the grid. The solution was very dilute to allow for a wide spacing of nannofossils on the grid. This thin coating helped avoid confusion when trying to find the same specimen with the SEM.

3. The slide was then examined with the $100 \times$ objective and with immersion oil over the dried sample. The locations of specimens photographed on the grid were noted.

4. When the light microscope work was completed, the slide was dipped three times in a bath of xylene, then washed three times in a bath of isopropyl alcohol. This removed the immersion oil but left the sample and the ink grid.

5. The slide was prepared for SEM by coating it lightly with paladium. Care was taken to apply only a thin coat of paladium so that the ink lines on the grid could still be discerned in the SEM.

6. The grid locations of the specimens already observed with the light microscope were then found, and the specimens were then photographed with the SEM.

\section{Abundances}

Estimates of abundances for individual species of nannofossils in each field of view at $1000 \times$ magnification are as follows:

$\mathrm{A}=$ abundant; 1 to 10 specimens per field of view

$\mathrm{C}=$ common; 1 specimen per 2 to 10 fields of view

$\mathrm{F}=$ few; 1 specimen per 11 to 100 fields of view

$\mathrm{R}=$ rare; 1 specimen per 101 to 1000 fields of view

$\mathrm{B}=$ barren; no nannofossils present 
Due to the nature of the sediments in the area, reworking of older nannofossils into the glacial intervals has greatly influenced nannofossil assemblage composition. During the glacial intervals, ice-rafted Cretaceous nannofossils diluted the Neogene assemblages. Due to the great importance that ice-rafting played on the percentage of reworked taxa found, an attempt was made to quantify the findings, and estimates of the percent of reworked nannofossils relative to in-situ taxa have been included on the range charts. Percentages are estimated to the nearest $10 \%$ from $10 \%$ to $100 \%$. Less than $10 \%$ reworking is stated as " $<10 \%$ " for 10 to $1 \%$, and less than $1 \%$ reworking is stated as " $N$ " for negligible.

\section{Preservation}

Preservation of the calcareous nannofossils found in each sample is recorded as follows:

$$
\begin{aligned}
\mathrm{G}= & \text { good; specimens show little effects of overgrowth and/or dis- } \\
& \text { solution. }
\end{aligned}
$$

\section{BIOSTRATIGRAPHY}

Taxa considered in this report are listed in the Appendix. Bibliographic references for these taxa are presented by Loeblich and Tappan (1966-1973), von Heck (1979a-1983), and Steinmetz (1984a-1985).

In the cores recovered on ODP Leg 104, calcareous nannofossils are present in Oligocene to Quaternary sediments and generally contain nannofossils in low abundance and diversity. Nannofossil diversity is highest in tropical waters and decreases towards the poles. Reduction in diversity of microfossils leads to fewer biostratigraphic events in the geologic record and thus to reduced biostratigraphic resolution. Nannofossils are absent in present-day arctic and antarctic waters (Kennett, 1982). This presents problems in the biostratigraphy.

The standard low-latitude zonations, such as Okada and Bukry (1980) and Martini (1971) (Table 1), cannot be followed in detail. These standard zonations of the Neogene are based primarily on the first occurrences and extinctions of discoasters, ceratoliths, and sphenoliths, which are generally missing in the Norwegian-Greenland Sea. Thus, these zonal schemes cannot be used in detail. Many of the zonal markers that do exist in the area are diachronous from low to high latitudes and cannot be used in world-wide correlations.

The nannofossils in the Norwegian-Greenland Sea are reduced by a number of factors: unfavorably low water temperatures, dilution by terrigenous sediments or siliceous fossils, and dissolution. The sea floor is also relatively shallow and no calcium carbonate compensation level exists (Kellogg, 1980), therefore dissolution is most likely due to the unfavorably low water temperatures.

Except during the Pleistocene, Coccolithus pelagicus and reticulofenestrids make up the bulk of the assemblages. These species are not excluded by the low temperatures; they are also dissolution resistant. Unfortunately, of these abundant species, only Reticulofenestra pseudoumbilica is a standard marker.

The main marker species of the Neogene are the ceratoliths, sphenoliths, and discoasters. No ceratoliths were found in any of the sites. The ceratoliths are relatively dissolution resistant and their absence in the Norwegian-Greenland Sea is due to lower than optimun temperatures more than to dissolution.

The sphenoliths, on the other hand, are easily dissolved. A few sphenoliths were found in the relatively warmer upper Miocene sediments, but their presence at that location is not stratigraphically important. Their absence could be due to the unfavorable environment or to selective dissolution.
The discoasters are highly dissolution resistant. Most of the standard zonal marker species are not present due to their preference for low latitudes. A few discoasters were found but these are generally unreliable for age determinations. Discoaster intercalcaris, a cold-water form of Discoaster variabilis (Bukry, 1971), is found in places, but its long range makes it impractical for biostratigraphy.

The standard nannofossil zonation of Martini (1971) was followed to the extent possible to promote continuity with the previous study by Müller (1976). Due to the absence of many marker species, however, various zones had to be combined into longer ranging zones. Thus, the biostratigraphic resolution of the nannofossils in the Norwegian-Greenland Sea is poor. The nannofossil zonation presented here is similar to that compiled for Leg 38 (Müller, 1976) (see Table 2) with the exception of the interval with Cyclicargolithus floridanus, which is delineated here. Zone NN4, the interval with Helicosphaera ampliaperta, was encountered on Leg 38 (Müller, 1976), but was not observed on Leg 104 due to the presence of a long nannofossil-barren interval which most likely includes this zone.

\section{Site Reports}

A total of eight holes were drilled and cored on Leg 104. Five holes, A, B, C, D, and E, were drilled at Site 642. Hole 642A consisted of one surface core and is not discussed due to its proximity to and overlap with Holes $642 \mathrm{~B}$ and C. Hole 642B was drilled to $221 \mathrm{mbsf}$. Hole $642 \mathrm{C}$ was drilled to $200 \mathrm{mbsf}$ and was offset vertically by approximately one-half of a core to obtain a continuous and more precise sedimentary record of the Neogene. Holes $642 \mathrm{D}$ and $642 \mathrm{E}$ were barren of nannofossils. Site 643 consisted of one hole drilled to a total depth of 562.5 mbsf. Site 644 consisted of two holes also offset by approximately one-half core. Hole $644 \mathrm{~A}$ was drilled to $252.8 \mathrm{mbsf}$, and Hole 644B was drilled to 127.7 mbsf.

\section{Site 642}

Site 642 represents the central point in the three-site traverse across the Vøring Margin. The objectives of this site relate to the paleoceanographic history of the Norwegian-Greenland Sea, specifically to the influence of the central part of the Norwegian Current in the area. Site 642 is located on the outer Vøring Plateau and consists of five holes within $450 \mathrm{~m}$ of each other. The drilled sequence consists of $318 \mathrm{~m}$ of predominantly pelagic and hemipelagic upper Cenozoic sediments overlying a 910-m volcanic, mostly basaltic, sequence with interbedded pyroclastic sediments.

\section{Hole 642B (Tables 3, 4)}

Quaternary samples containing nannofossils were recovered from the uppermost $40 \mathrm{~m}$ in Hole 642B. The sediments alternate between glacial and interglacial deposition. The interglacial sediments often contain nannofossil ooze layers with abundant assemblages of Gephyrocapsa sp., Coccolithus pelagicus, and small reticulofenestrids. Also present, but less frequent, are Braarudosphaera bigelowii, Cyclococcolithus leptoporus, Dictyococcites sp., Discolithina sp., Helicosphaera carteri, Syracosphaera sp., and Thoracosphaera sp.

Emiliania huxleyi, the marker for the E. huxleyi Zone (NN21), was identified in samples with the use of SEM to $13 \mathrm{mbsf}$ (Section 104-642B-2-6, $85 \mathrm{~cm}$ ). Unusually large specimens of $E$. huxleyi, up to $5 \mu \mathrm{m}$, are often observed in Core 104-642B-1. Neither E. huxleyi nor Pseudoemiliania lacunosa are found at $14 \mathrm{~m}$ (Section 104-642B-3-1, $18 \mathrm{~cm}$ ), indicating the presence of the Gephyrocapsa oceanica Zone (NN20).

The zonal marker for NN19-16, Pseudoemiliania lacunosa, is first observed at 21 mbsf (Section 104-642B-4-1, $17 \mathrm{~cm}$ ). The 
Table 1. Standard low-latitude nannofossil zonations of Okada and Bukry (1980) and Martini (1971) (from Okada and Bukry, 1980).

\begin{tabular}{|c|c|c|c|c|c|c|c|}
\hline Age & \multicolumn{2}{|r|}{ Zone } & & Subzone & \multirow{2}{*}{$\begin{array}{c}\begin{array}{c}\text { Martini } \\
\text { (1971) } \\
\text { Zone }\end{array} \\
\text { NN21 } \\
\end{array}$} & \multirow{3}{*}{$\begin{array}{c}\begin{array}{c}\text { Dura- } \\
\text { tion } \\
\text { (m.y.) }\end{array} \\
0.2 \\
0.1\end{array}$} & \multirow{3}{*}{$\begin{array}{c}\begin{array}{c}\text { Boun- } \\
\text { dary } \\
\text { (Ma) }\end{array} \\
0.2 \\
\end{array}$} \\
\hline \multirow{5}{*}{ 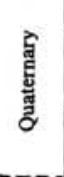 } & CN15 & \multicolumn{3}{|l|}{ Emiliania huxleyi } & & & \\
\hline & \multirow{2}{*}{$\mathrm{CN} 14$} & \multirow{2}{*}{$\begin{array}{l}\text { Gephyrocapsa } \\
\text { oceanica }\end{array}$} & $\mathrm{CN} 14 \mathrm{~b}$ & Ceratolithus cristatus & NN20 & & \\
\hline & & & $\mathrm{CN} 14 \mathrm{a}$ & Emiliania ovata & \multirow{3}{*}{ NN19 } & 0.6 & 0.3 \\
\hline & \multirow{2}{*}{ CN13 } & \multirow{2}{*}{$\begin{array}{l}\text { Crenalithus } \\
\text { doronicoides }\end{array}$} & CN13b & Gephyrocapsa caribbeanica & & 0.7 & 0.9 \\
\hline & & & $\mathrm{CN} 13 \mathrm{a}$ & Emiliania annula & & 0.2 & $\frac{1.0}{18}$ \\
\hline \multirow{8}{*}{ 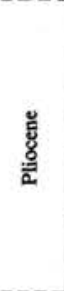 } & \multirow{4}{*}{$\mathrm{CN} 12$} & \multirow{4}{*}{$\begin{array}{l}\text { Discoaster } \\
\text { brouweri }\end{array}$} & $\mathrm{CN} 12 \mathrm{~d}$ & Calcidiscus macintyrei & NN18 & 0.2 & 1.0 \\
\hline & & & $\mathrm{CN} 12 \mathrm{c}$ & Discoaster pentaradiatus & NN17 & 0.1 & 2.0 \\
\hline & & & $\mathrm{CN} 12 \mathrm{~b}$ & Discoaster surculus & NN16 & 0.4 & 2.1 \\
\hline & & & $\mathrm{CN} 12 \mathrm{a}$ & Discoaster tamalis & & 0.5 & 2.5 \\
\hline & \multirow{2}{*}{ CN11 } & Reticulofenestra & CNIIb & Discoaster asymmetricus & NN15 & 0.5 & 3.0 \\
\hline & & & CN11a & Sphenolithus neoabies & & 0.5 & 3.5 \\
\hline & & Amarolithus & $\mathrm{CN} 10 \mathrm{c}$ & Ceratolithus rugosus & $13 / 14$ & 0.4 & 4.0 \\
\hline & CN10 & tricorniculatus & $\mathrm{CN} 10 \mathrm{~b}$ & Ceratolithus acutus & NN12 & 0.6 & 4.4 \\
\hline & & & CN10a & Triquetrorhabdulus rugosus & & 0.6 & 5.0 \\
\hline & $\mathrm{CN} 9$ & Discoaster & CN9b & Amaurolithus primus & NN11 & 1.0 & 5.6 \\
\hline & & quinqueramus & $\mathrm{CN9a}$ & Discoaster berggreni & 年 & 0.4 & 6.6 \\
\hline & CN8 & Discoaster & CN8b & Discoaster neorectus & NN10 & 0.5 & 7.0 \\
\hline & & neohamatus & CN8a & Discoaster bellus & 2010 & 3.5 & 7.5 \\
\hline & $\mathrm{CN} 7$ & Discoaster & CN7b & Catinaster calyculus & NN9 & 1.0 & 11.0 \\
\hline & & hamatus & CN7a & Helicosphaera carteri & & 1.0 & 12.0 \\
\hline 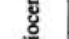 & CN6 & Catinaster coalitus & & & NN8 & 0.2 & 13.0 \\
\hline $\bar{\Sigma}$ & CN5 & Discoaster exilis & CN5b & Discoaster kugleri & NN7 & 0.2 & 13.2 \\
\hline & & & CN5a & Coccolithus miopelagicus & NN6 & 0.6 & 13.4 \\
\hline & $\mathrm{CN} 4$ & Sphenolithus heteron & iorphus & & & 1.0 & 14.0 \\
\hline & $\mathrm{CN} 3$ & Helicosphaera ampli & perta & & NN5 & 2.0 & 15.0 \\
\hline & $\mathrm{CN} 2$ & Sphenolithus belemn & & & NN2 & 1.0 & 17.0 \\
\hline & & & CNIc & Discoaster druggii & & 3.0 & 18.0 \\
\hline & CN1 & carinatus & $\mathrm{CN} 1 \mathrm{~b}$ & Discoaster deflandrei & NN1 & 2.0 & 21.0 \\
\hline & & & $\mathrm{CNla}$ & Cyclicargolithus abisectus & & 1.0 & 23.0 \\
\hline & CP19 & Sphenolithus & $\mathrm{CP} 19 \mathrm{~b}$ & Dictyococcites bisectus & NP25 & 1.0 & 24.0 \\
\hline & & ciperoensis & CP19a & Cyclicargolithus floridanus & NP24 & 1.5 & 25.0 \\
\hline हूँ & CP18 & Sphenolithus distent & & & NP23 & 3.5 & 26.5 \\
\hline 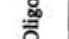 & CP17 & Sphenolithus predist & ntus & & & 4.0 & 30.0 \\
\hline & & & CP16c & Reticulofenestra hillae & NP22 & 0.5 & 34.0 \\
\hline & CP16 & reticulata & $\mathrm{CP} 16 \mathrm{~b}$ & Coccolithus formasus & NP21 & 2.5 & 34.5 \\
\hline & & & CP16a & Coccolithus subdistichus & & 1.0 & 37.0 \\
\hline & CP15 & Discoaster & CP15b & Isthmolithus recurvus & $19 / 20$ & 3.0 & 38.0 \\
\hline & & barbadiensis & CP15a & Chiasmolithus oamaruensis & NP18 & 1.0 & 41.0 \\
\hline & CP14 & Reticulofenestra & CP14b & Discoaster saipanensis & NP17 & 2.0 & 42.0 \\
\hline & & umbilica & CP14a & Discoaster bifax & & 1.0 & 44.0 \\
\hline & & & CP13c & Coccolithus staurion & NP16 & 1.5 & 45.0 \\
\hline & CP13 & quadrata & CP13b & Chiasmolithus gigas & NP15 & 0.5 & 46.5 \\
\hline ర్ & & & CP13a & Discoaster strictus & & 1.0 & 47.0 \\
\hline & CP12 & Discoaster & $\mathrm{CP} 12 \mathrm{~b}$ & Rhabdosphaera inflata & NP14 & 1.0 & 48.0 \\
\hline & & sublodoensis & CP12a & Discoasteroides kuepperi & & 0.5 & 49.0 \\
\hline & CP11 & Discoaster lodoensis & & & $12 / 13$ & 0.5 & 49.5 \\
\hline & CP10 & Tribrachiatus orthost & lus & & & 2.0 & 50.0 \\
\hline & CP9 & Discoaster & $\mathrm{CP} 9 \mathrm{~b}$ & Discoaster binodosus & NP11 & 0.8 & 52.0 \\
\hline & & diastypus & СР9a & Tribrachiatus contortus & NP10 & 0.7 & 52.8 \\
\hline & CP8 & Discoaster & CP8b & Campylosphaera eodela & NP9 & 0.5 & 53.5 \\
\hline & & multiradiatus & CP8a & Chiasmolithus bidens & & 1.0 & 54.0 \\
\hline & $\mathrm{CP7}$ & Discoaster nobilis & & & $7 / 8$ & 0.5 & 55.0 \\
\hline & CP6 & Discoaster mohleri & & & & 1.5 & 55.5 \\
\hline Еัّ & CP5 & Heliolithus kleinpell & & & NP6 & 1.0 & 57.0 \\
\hline ल्ँ & $\mathrm{CP} 4$ & Fasciculithus tympan & formis & & NP5 & 2.0 & 58.0 \\
\hline & $\mathrm{CP} 3$ & Ellipsolithus macellu & & & NP4 & & 60.0 \\
\hline & $\mathrm{CP} 2$ & Chiasmolithus danic & & & NP3 & & \\
\hline & CP1 & Zygodiscus & CPlb & Cruciplacolithus tenuis & NP2 & & \\
\hline & & sigmoides & CPla & Cruciplacolithus primus & NP1 & & 65.0 \\
\hline
\end{tabular}


Table 2. Nannofossil zonation of DSDP Leg 38 (Müller, 1976).

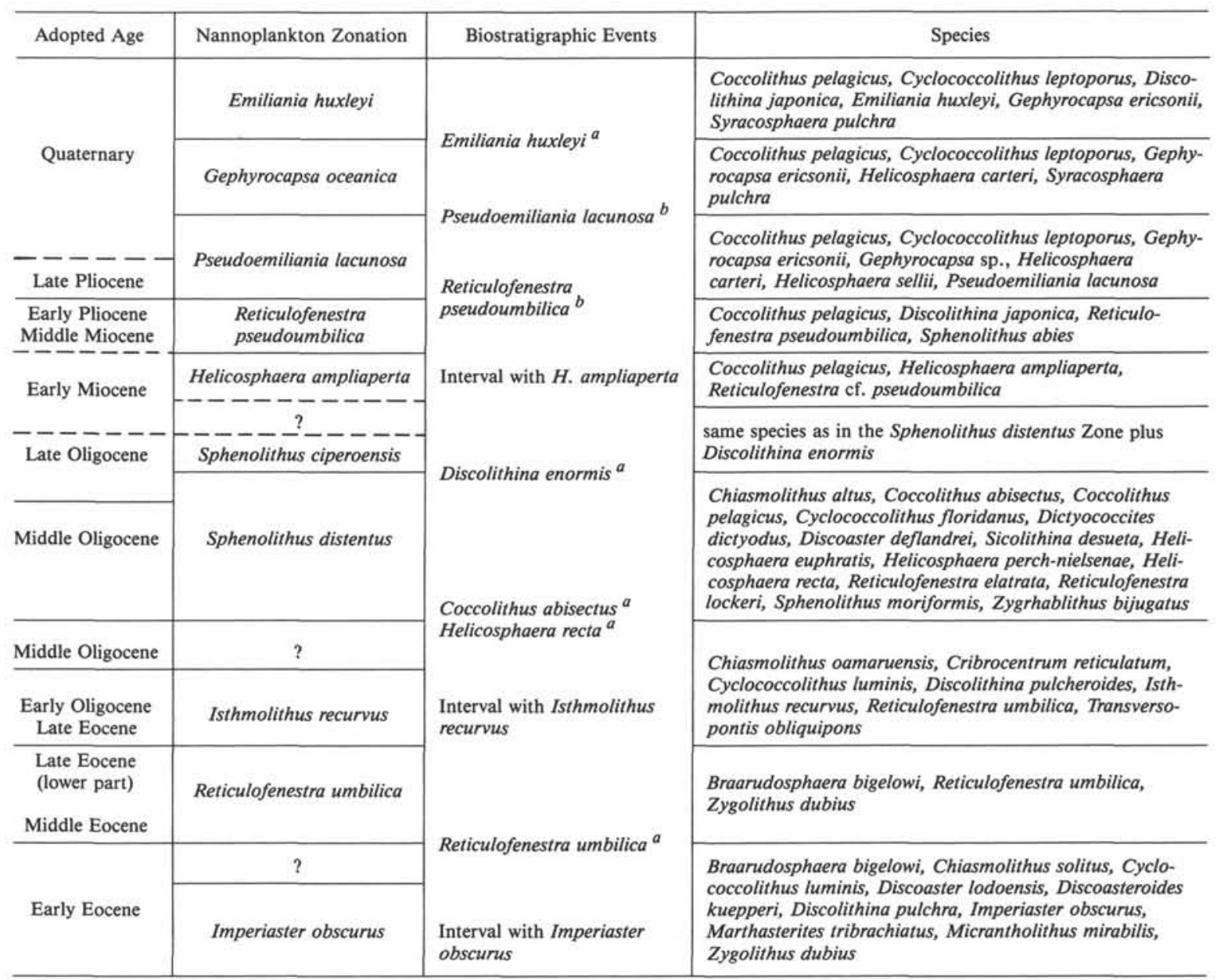

\footnotetext{
${ }^{a}$ First occurence.

${ }^{\mathrm{b}}$ Last occurrence.
}

LAD of $P$. lacunosa is often difficult to determine due to its scarcity near its extinction level.

A barren to near-barren zone exists within Zone NN19-16 from 40 to 68 mbsf. Helicosphaera sellii is found at $68 \mathrm{mbsf}$. Gartner (1977) used $H$. sellii for a datum to further define the Pleistocene, but the true LAD of $H$. sellii most likely occurs within the barren interval of Hole $642 \mathrm{~B}$ and thus cannot be used for an accurate age determination. Backman and Shackleton (1983) found-this taxon to be time transgressive even at mid to low latitudes.

The LAD of Reticulofenestra pseudoumbilica, the zonal marker for NN15-7, is at 78 mbsf (Section 104-642B-10-2, $96 \mathrm{~cm}$ ). This zone often contains abundant nannofossils but of low diversity. The assemblage consists mostly of Coccolithus pelagicus, small reticulofenestrids, and Reticulofenestra pseudoumbilica. Also occurring within this zone are Braarudosphaera bigelowii, Calcidiscus leptoporus, Dictyococcites sp., Discolithina sp., Helicosphaera carteri, H. sellii, Syracosphaera sp., Thoracosphaera sp., and Sphenolithus moriformis. The only discoasters present are Discoaster intercalcaris and Discoaster variabilis, which are high-latitude forms with long ranges that coincide closely with the range of Reticulofenestra pseudoumbilica. The FAD of Pseudoemiliania lacunosa occurs a few meters higher than the LAD of Reticulofenestra pseudoumbilica, and the FAD of Gephyrocapsa occurs approximately 10 to $20 \mathrm{~m}$ upcore from the LAD of Reticulofenestra pseudoumbilica. Within this interval are two barren zones; one from 84 to $103 \mathrm{mbsf}$, and the other from 113 to 125 mbsf.

The LAD of Cyclicargolithus floridanus is at $156 \mathrm{mbsf}$ (Section 104-642B-18-6, $100 \mathrm{~cm}$ ). According to Backman (1984) and Bukry (1973), this corresponds to the top of NN6. Roth and Thierstein (1972) mention that this species has been recorded in the overlying Discoaster kugleri Subzone in some areas, and Miller et al. (1985) also show Cyclicargolithus floridanus occurring in NN7. The LAD of $C$. floridanus found at Site 642 probably coincides with the data of Backman (1984) and Bukry (1973) in representing the NN6/NN7 boundary because it is found with the LAD of Cyclicargolithus abisectus, which also represents the NN6/NN7 boundary (Backman, 1984). This boundary corresponds to the top of the interval with $C$. floridanus (NN611). Also present in this zone are Braarudosphaera bigelowii, Coccolithus miopelagicus, C. pelagicus, Dictyococcites sp., Discoaster deflandrei, D. intercalcarius, D. variabilis, Discolithina sp., Helicosphaera carteri, $H$. paleocarteri, Reticulofenestra pseudoumbilica, small reticulofenestrids, Sphenolithus moriformis, and Syracosphaera sp.

Below 162 mbsf (Section 104-642B-19-4, $8 \mathrm{~cm}$ ), Hole 642B is mostly barren of nannofossils. Helicosphaera ampliaperta, the zonal marker for NN4, and Discolithina enormis, the marker for NP25, were found in Leg 38 sediments (Müller, 1976), but were not encountered in Hole 642B. This is probably due to the fact that the barren interval encompasses these intervals. 
Table 3. Relative abundance of nannofossils found in selected intervals from Hole 642B.

\begin{tabular}{|c|c|c|c|c|c|c|c|c|c|c|c|c|c|c|c|c|c|c|c|c|}
\hline $\begin{array}{l}\text { Core-Section, } \\
\text { interval }(\mathrm{cm})\end{array}$ & 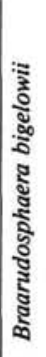 & 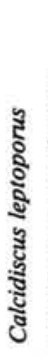 & 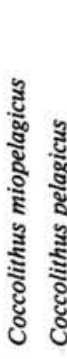 & 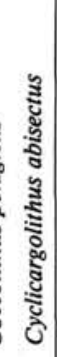 & 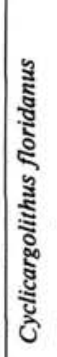 & 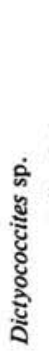 & 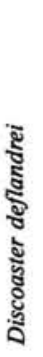 & 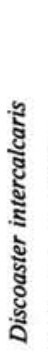 & 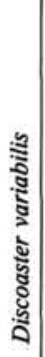 & 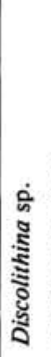 & 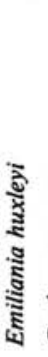 & 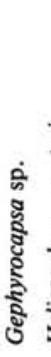 & 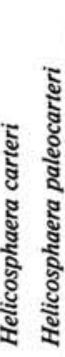 & 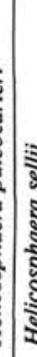 & 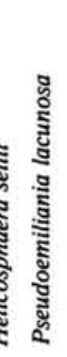 & 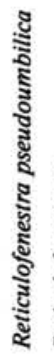 & & 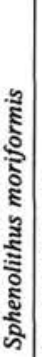 & 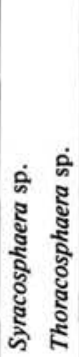 & \\
\hline $1-1,30$ & $\mathbf{R}$ & F & F & . & . & $\mathbf{R}$ & . & . & . & . & F & F & $\mathbf{R}$ & . & . & . & F & . & R $\quad R$ & $1-1,30$ \\
\hline $2-2,85$ & & . & C & . & . & $\mathrm{F}$ & . & . & . & & A & A & : & . & . & . & R & . & & $2-2,85$ \\
\hline $2-6,85$ & $\mathbf{R}$ & . & . $\mathrm{F}$ & . & . & $\mathbf{R}$ & . & . & . & R & C & C & . & 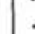 & . & . & C & . & & $2-6,85$ \\
\hline $3-2,87$ & . & R & . $F$ & . & . & $\mathbf{R}$ & . & . & . & R & . & C & . & . & . & . & C & . & R F & $3-2,87$ \\
\hline $3-4,18$ & . & . & . $\mathrm{C}$ & . & . & A & . & . & . & . & . & A & . & 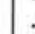 & 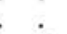 & . & A & . & $\mathrm{R} R$ & $3-4,18$ \\
\hline $4-1,107$ & . & F & . $\mathrm{F}$ & . & . & . & . & . & . & & & A & . & & C & . & C & . & & $4-1,107$ \\
\hline $4-5,107$ & . & F & . $\mathrm{C}$ & . & . & & . & . & . & . & . & & . & . & . & . & F & . & . $\mathbf{R}$ & $4-5,107$ \\
\hline $5-4,26$ & . & C & . $\mathrm{F}$ & . & . & F & . & . & . & & & A & & & F & . & A & & & $5-4,26$ \\
\hline $8-1,103$ & . & . & . $\mathrm{R}$ & . & . & $\mathrm{R}$ & . & . & . & . & . & $\mathrm{R}$ & . & & & . & R & . & . $\mathbf{R}$ & $8-1,103$ \\
\hline $9-2,6$ & & F & . $\mathrm{A}$ & . & & A & . & . & & $\mathbf{R}$ & & & & & F & . & A & & & $9-2,6$ \\
\hline $10-1,6$ & . & F & . $\mathrm{A}$ & . & . & $\mathrm{F}$ & . & . & . & . & . & . & . & F & C & . & A & F & . & $10-1,6$ \\
\hline $10-2,96$ & & C & A & . & & . & . & . & & & . & & & $\mathrm{F}$ & . & C & A & & & $10-2,96$ \\
\hline $11-4,6$ & $\mathbf{R}$ & C & A & . & . & & 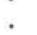 & . & & C & . & . & $\mathbf{R}$ & & . & F & A & & . & 11-4, \\
\hline $13-3,16$ & . & C & A & & & C & 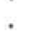 & F & F & C & . & . & $\mathrm{F}$ & c & . & C & A & $\mathbf{R}$ & & $13-3,16$ \\
\hline $16-1,10$ & & . & A & 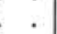 & . & A & . & R & R & $\mathbf{R}$ & . & . & F & F & . & C & A & C & . & $16-1,10$ \\
\hline $17-6,10$ & . & . & C & 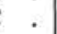 & & & 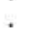 & . & . & . & . & . & C C & . & . & F & C & & & $17-6,10$ \\
\hline $18-5,102$ & & . & R & & & C & & $\mathbf{R}$ & . & R & . & . & C & . & . & F & A & $\mathbf{R}$ & . & $18-5,102$ \\
\hline $18-6,102$ & & . & $\mathrm{R} A$ & 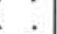 & $\mathbf{R}$ & C & $\dot{R}$ & . & . & $\mathrm{F}$ & . & . & C & . & . & C & A & $\mathrm{F}$ & & $18-6,102$ \\
\hline $19-4,8$ & $\mathbf{R}$ & . & R A & F & F & C & . & & . & & . & . & $\mathrm{F}$ & . & . & C & A & & $\mathbf{R}$ & $19-4,8$. \\
\hline
\end{tabular}

Table 4. Total ranges of nannofossils found in selected intervals from Hole 642B.

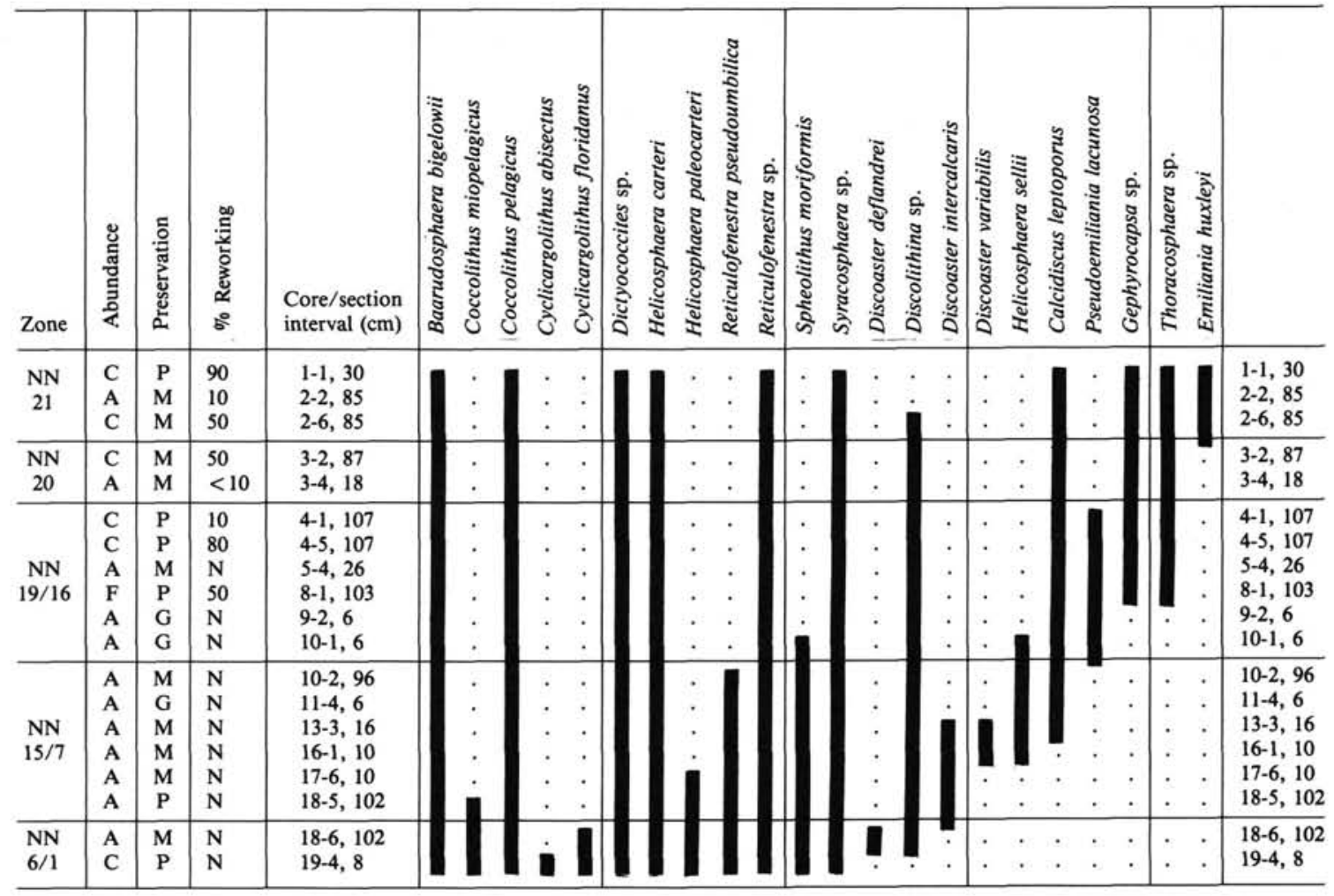




\section{Hole $642 \mathrm{C}$}

The depth (and sample numbers) of the zonal markers in Hole $642 \mathrm{C}$ are as follows:

FAD Emiliania huxleyi: 14 mbsf (Section 104-642C-3-1, $16 \mathrm{~cm}$ ).

LAD Pseudoemiliania lacunosa: 20 mbsf (Section 104-642C$3-5,6 \mathrm{~cm})$.

LAD Reticulofenestra pseudoumbilica: 82 mbsf (Section 104642C-11, CC).

LAD Cyclicargolithus floridanus: 158 mbsf (Section 104642C-19, CC).

The assemblages occurring within these zones are similar to those in Hole 642B.

\section{Site 643}

Site 643 is the deepest and most seaward site on the three-site transect. This single-bit hole was located on the lower slope near the foot of the outer Vøring Plateau. This site provides a record of the depositional environments under the seaward boundary of the Norwegian Current in water depths close to the Norwegian Sea Basin floor. A 565-m-thick pelagic and hemipelagic sedimentary sequence was drilled. The oldest sediments recovered are of early Eocene age.

\section{Hole 643 A (Tables 5, 6)}

The abundance of nannofossils at Site 643 was generally poor, except for a few rich intervals in the upper Pliocene-Pleistocene. The interval from 100 mbsf to total depth was mostly barren of nannofossils with the exception of a few scattered samples which contain a generally low diversity assemblage.

Emiliania huxleyi, the marker for Zone NN21, was found to a depth of 7 mbsf (Section 104-643A-2-1, $125 \mathrm{~cm}$ ). Also present are Gephyrocapsa sp., Coccolithus pelagicus, small reticulofenestrids, Braarudosphaera bigelowii, Calcidiscus leptoporus, Dictyococcites sp., Helicosphaera carteri, Syracosphaera sp., and Thoracosphaera sp. Neither Emiliania huxleyi nor Pseudoemiliania lacunosa were found between 7 and $12 \mathrm{mbsf}$, thus indicat- ing Zone NN20. The marker for the top of NN19-16, the LAD of $P$. lacunosa, is at $12 \mathrm{mbsf}$ (Section 104-643A-2-5, $50 \mathrm{~cm}$ ). Two intervals barren of nannofossils occur within this zone from 32 to $56 \mathrm{mbsf}$, and from 64 to $71 \mathrm{mbsf}$. The last occurrence of $\mathrm{He}$ licosphaera sellii is at 56 mbsf (Section 104-643A-7-3, $49 \mathrm{~cm}$ ), which is just below a $24-\mathrm{m}$ interval barren of nannofossils. Thus, this occurrence did not represent the true LAD of $\mathrm{H}$. sellii and could not be used as a reliable marker species for the lower Pleistocene.

The marker species for Zone NN15-7, Reticulofenestra pseudoumbilica, was observed at a depth of 75 mbsf (Section 104$643 \mathrm{~A}-9-2,125 \mathrm{~cm})$. The assemblage consists primarily of Coccolithus pelagicus, small reticulofenestrids, and Reticulofenestra pseudoumbilica, with lesser abundances of Braarudosphaera bigelowii, Calcidiscus leptoporus, Dictyococcites sp., Discolithina sp., Discoaster intercalcaris, D. variabilis, Helicosphaera carteri, H. sellii, Sphenolithus moriformis, Syracosphaera sp., and Thoracosphaera sp. This assemblage, representing Zone NN15-7, occurs to a depth of 100 mbsf. Below $100 \mathrm{~m}$, the sediment is almost entirely barren of calcareous nannofossils, with the exception of two short intervals that contain poorly preserved assemblages. At 141 mbsf (Section 104-643A-16-3, 49 $\mathrm{cm})$, Cyclicargolithus floridanus is present. Thus, the boundary betwen NN15-7 and NN6-1 is between 100 and 141 mbsf.

The final Hole 643A interval that contains nannofossils extends from 409 to 410 mbsf (Section 104-643A-43, CC). The samples at 409 and 410 mbsf contain basically the same assemblages with Cyclicargolithus floridanus present, except that the upper Oligocene marker, Discolithina enormis, occurs at 410 mbsf. Thus, the boundary between NN6-1 and NP25 occurs at 410 mbsf. Because the remainder of the core is barren, the FAD of $D$. enormis, and thus the lower boundary of NP25, could not be determined.

\section{Site 644}

Site 644 represents the landward end of the three-site transect. It is located in the Vøring Basin at a shallow depth close to

Table 5. Relative abundance of nannofossils found in selected intervals at Site 643.

\begin{tabular}{|c|c|c|c|c|c|c|c|c|c|c|c|c|c|c|c|c|c|c|c|c|c|c|c|c|}
\hline $\begin{array}{l}\text { Core-Section, } \\
\text { interval }(\mathrm{cm})\end{array}$ & 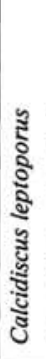 & 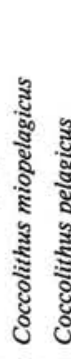 & 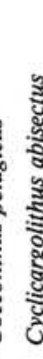 & 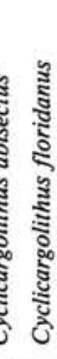 & 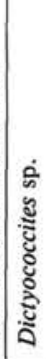 & 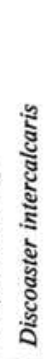 & 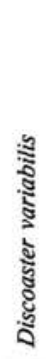 & 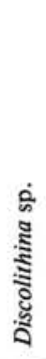 & 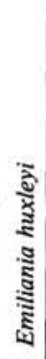 & 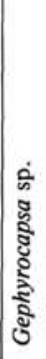 & 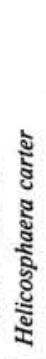 & 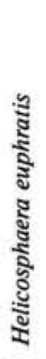 & 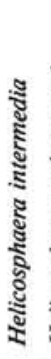 & 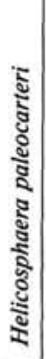 & 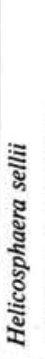 & 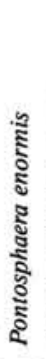 & 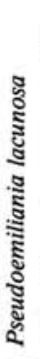 & 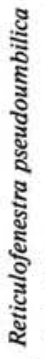 & 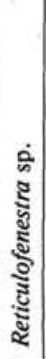 & 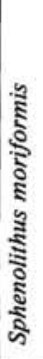 & 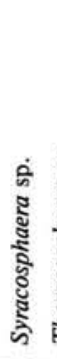 & 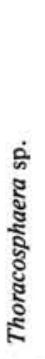 & & $\begin{array}{l}\text { Core-Section, } \\
\text { interval }(\mathrm{cm})\end{array}$ \\
\hline $1-1,50$ & F & C & . & & F & . & . & $\mathrm{F}$ & C & C & $\mathbf{R}$ & . & . & . & . & . & . & . & C & . & $\mathrm{R}$ & F & & $1-1,50$ \\
\hline $1-2,50$ & R & . $\mathrm{C}$ & . & & $\mathrm{F}$ & . & . & $\mathrm{F}$ & C & c & . & . & : & . & . & : & : & . & C & . & . & . & & $1-2,50$ \\
\hline $1-3,50$ & . & . $\mathrm{F}$ & . & & . & . & . & $\mathrm{R}$ & . & $\mathrm{F}$ & . & . & . & . & . & . & . & . & $\mathrm{F}$ & . & . & $\mathrm{R}$ & & $1-3,50$ \\
\hline $2-2,125$ & R & . $\mathrm{F}$ & . & & F & . & . & . & . & . & . & . & . & . & . & . & . & . & F & . & . & . & & $2-2,125$ \\
\hline $2-4,125$ & $\mathrm{~F}$ & . $\mathrm{F}$ & . & & $\mathrm{F}$ & . & . & . & & $\mathrm{F}$ & . & . & . & . & . & . & . & . & F & . & & . & & $2-4,125$ \\
\hline $2-5,125$ & $\mathrm{R}$ & . C & . & & C & . & . & . & . & A & . & . & . & . & . & . & $\mathrm{R}$ & . & A & . & . & . & & $2-5,125$ \\
\hline $3-2,49$ & $\mathrm{~F}$ & F & . & & C & . & . & & . & A & $\mathrm{R}$ & . & . & . & . & . & . & . & A & . & F & . & & $3-2,49$ \\
\hline $3-4,49$ & $\mathrm{R}$ & C & . & & F & . & . & $\mathrm{R}$ & . & . & . & . & . & . & . & . & . & . & $\mathrm{F}$ & . & . & . & & $3-4,49$ \\
\hline $3-6,49$ & C & . & . & & C & . & . & $\mathrm{R}$ & . & A & . & . & . & & . & . & & . & A & • & . & & & $3-6,49$ \\
\hline $4-2,123$ & $\mathrm{~F}$ & $\mathrm{R}$ & . & . & . & . & . & R & . & . & . & . & . & . & . & . & F & . & $\mathrm{F}$ & . & . & $\mathrm{R}$ & & $4-2,123$ \\
\hline $7-3,49$ & $\mathrm{~F}$ & A & . & . & A & R & $\mathrm{R}$ & . & . & $F$ & . & . & . & . & $R$ & . & F & . & A & . & . & . & & $7-3,49$ \\
\hline $7-5,126$ & C & C & . & . & A & . & . & . & . & . & . & . & . & . & . & . & $\mathrm{F}$ & . & A & . & . & . & & $7-5,126$ \\
\hline $9-1,125$ & . & C & . & . & C & . & . & & . & . & . & . & . & & . & . & . & . & C & & . & . & & $9-1,125$ \\
\hline $9-2,125$ & . & A & . & . & A & . & . & C & . & . & . & . & . & $\mathrm{R}$ & . & . & . & $\mathrm{R}$ & & & . & . & . & $9-2,125$ \\
\hline $10-1,49$ & . & . C & 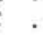 & & C & . & . & . & . & . & & 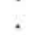 & & & . & . & . & $\mathrm{F}$ & F & $\mathbf{R}$ & & & & $10-1,49$ \\
\hline $10-4,149$ & . & A & . & & C & . & . & . & . & . & $\mathrm{R}$ & . & . & $\mathrm{R}$ & . & . & . & F & C & $\mathrm{F}$ & . & . & . & $10-4,149$ \\
\hline $11-6,50$ & $\mathbf{R}$ & A & & . & A & $\mathrm{R}$ & $\mathrm{R}$ & . & . & . & $\mathbf{R}$ & . & & . & . & . & . & C & A & . & & . & & $11-6,50$ \\
\hline $43-C C, 5-6$ & . & A & $\mathrm{F}$ & C $C$ & . & . & . & . & . & . & . & . & . & . & . & . & . & . & $\mathrm{F}$ & & . & . & . & $43-C C, 5-6$ \\
\hline 43- $\mathrm{CC}$ & . & - A & & $C$ & R & & & F & . & . & & & & & . & $\mathrm{R}$ & . & . & $\mathrm{F}$ & $\mathrm{F}$ & . & . & & 43-CC \\
\hline
\end{tabular}


Table 6. Total ranges of nannofossils found in selected intervals at Site 643 .

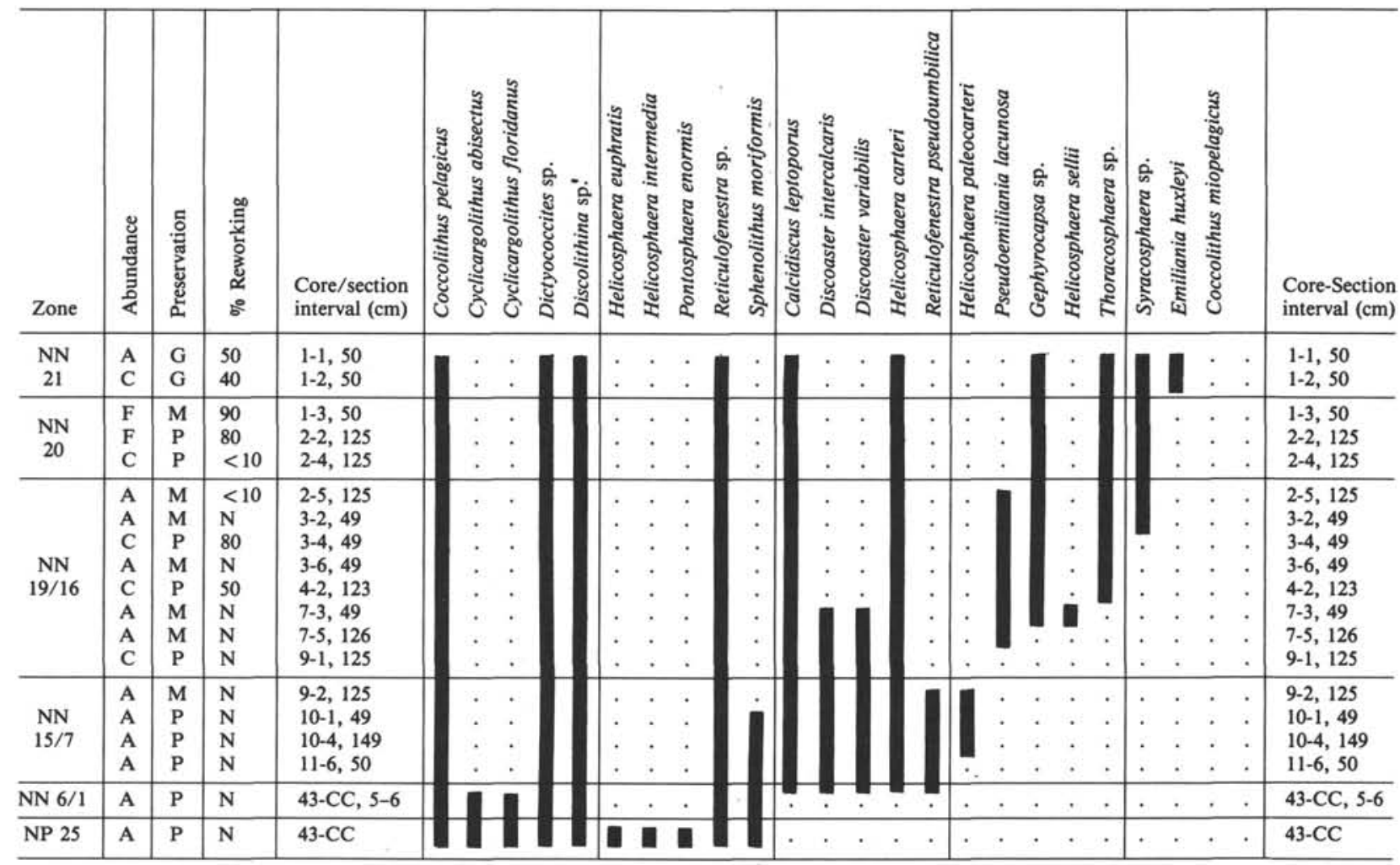

the inner continental slope. It overlies subsided old continental crust. This site, as well as Site 642, was double APC cored for greater resolution.

\section{Hole 644 A (Tables 7, 8)}

Due to safety concerns, Site 644 could only be drilled to a depth of 250 mbsf. The sediment recovered contained three nannofossil zones and a detailed record of glacial-interglacial deposition (Tables 7, 8).

Emiliania huxleyi, the marker for NN21, is present down to 26 mbsf (Section 104-644A-4-1, 50 cm). The assemblage consists of small reticulofenestids, Acanthoica sp., Braarudosphaera bigelowii, Coccolithus pelagicus, Calcidiscus leptoporus, E. huxleyi, Dictyococcites sp., Discolithina sp., Helicosphaera carteri, Syracosphaera sp., and Thoracosphaera sp, as well as the same high numbers of reworked Cenozoic and Paleogene nannofossils found in Sites 642 and 643.

The marker for NN19-16, Pseudoemiliania lacunosa first occurs at 51 mbsf (Section 104-644A-6-5, $50 \mathrm{~cm}$ ). Reticulofenestra pseudoumbilica was not encountered and the hole terminated in Zone NN19-16. In Hole 642B, the FAD of Pseudoemiliania lacunosa was observed $2 \mathrm{~m}$ above the LAD of Reticulofenestra pseudoumbilica. In Hole 644A, the FAD of Pseudoemiliania lacunosa was observed $6 \mathrm{~m}$ before total depth was reached (Section 104-644A-33-1, $50 \mathrm{~cm}$ ), indicating the possible proximity to the LAD of Reticulofenestra pseudoumbilica.

\section{Abundance, Preservation, and Reworking}

The abundance of calcareous nannofossils at Site 644 is greater than at Sites 642 and 643. At Site 644, the PliocenePleistocene nannofossils found in the interglacial sediments are usually common to abundant, while at Sites 642 and 643 they are typically few to rare. All three sites contain a zone barren of nannofossils between the interval with Pseudoemiliania lacunosa and the interval with Reticulofenestra pseudoumbilica.
The barren interval includes the Pliocene/Pleistocene boundary. Sites 642 and 643 contain extensive barren intervals below the last occurance of Cyclicargolithus floridanus (Fig. 1). Preservation of the nannofossils varies greatly throughout the sedimentary section. The glacial sediments are characterized by poor preservation while the interglacial intervals often contain wellpreserved nannofossil oozes. The Pliocene, as a general rule, contains moderately to poorly preserved nannofossils while the late-middle Miocene nannofossils are often moderately to well preserved. The preservation at Site 644 is better than at the other two sites. Moderate to good preservation is common at Site 644 , compared to the poor to moderate preservation at Sites 642 and 643 (see discussion below).

Both the abundance and preservation of the nannofossils decline toward the deeper water sites; the nannofossils are most abundant and well preserved at Site 644, decline at Site 642, and are least abundant and have the poorest preservation at the deep Site 643. This is most likely due to increased dissolution at the greater depths of deposition and the reduced influence of the Norwegian Current farther out to sea. Site 643 is located at a water depth twice that of the other two sites (about $2700 \mathrm{~m}$ for Site 643 as compared to about $1225 \mathrm{~m}$ and $1300 \mathrm{~m}$ for Sites 644 and 642 , respectively). The poor preservation could be due to the increased exposure of the nannofossils to the relatively cold and corrosive water column below the Norwegian Current. But, even though Sites 642 and 644 are located in approximately the same water depth, they are characterized by differences in abundance and preservation, Site 642 containing the poorer assemblages. This could be due to the effect of the Norwegian Current. The current is responsible for transporting warm, relatively productive surface waters into the Norwegian-Greenland Sea from the North Atlantic. This current has varying effects on the three sites. The current is relatively warm and extensive over Site 644 , but becomes diluted by colder, less productive surface currents (East Icelandic Current) further out to sea over Site 643 
Table 7. Relative abundance of nannofossils found in selected intervals in Hole 644A.

\begin{tabular}{|c|c|c|c|c|c|c|c|c|c|c|c|c|c|c|c|}
\hline $\begin{array}{l}\text { Core-Section, } \\
\text { interval }(\mathrm{cm})\end{array}$ & 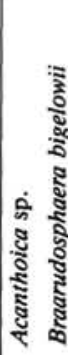 & 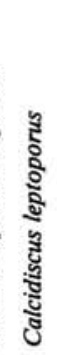 & 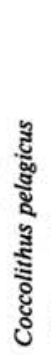 & 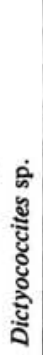 & 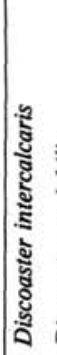 & 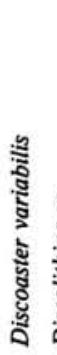 & 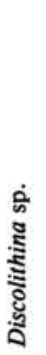 & 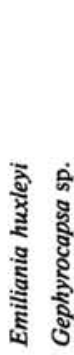 & 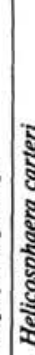 & 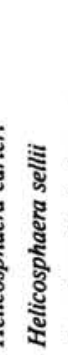 & 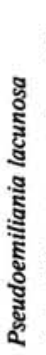 & 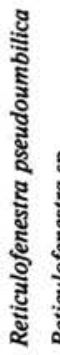 & 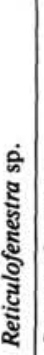 & 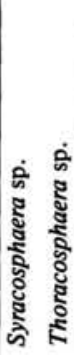 & $\begin{array}{l}\text { Core-Section, } \\
\text { interval }(\mathrm{cm})\end{array}$ \\
\hline $1-1,50$ & $\mathrm{R}$ & $\mathbf{R}$ & $\mathbf{R}$ & F & . & . & $\mathbf{R}$ & C F & $\mathrm{R}$ & . & . & . & F & $\mathbf{R} \quad \mathbf{R}$ & $1-1,50$ \\
\hline 2. & . & $\mathrm{F}$ & $\mathrm{F}$ & . & : & : & $\mathrm{R}$ & $\mathrm{F} A$ & $\mathrm{R}$ & : & : & : & A &. & \\
\hline 4 & & $\mathbf{R}$ & $\mathrm{F}$ & $\mathbf{R}$ & . & & . & R F & . & & . & & $\mathrm{F}$ & & $4-1,50$ \\
\hline 2,5 & & $\mathrm{~F}$ & C & C & . & . & & - A & $\mathrm{R}$ & . & . & . & C & . & $4-2,50$ \\
\hline $5-4,125$ & & $\mathrm{~F}$ & C & $\mathrm{F}$ & . & . & F & & $\mathrm{R}$ & . & . & & C & & $5-4,125$ \\
\hline $6-3,125$ & & $\mathrm{~F}$ & C & $\mathrm{F}$ & . & . & $\mathbf{R}$ & . C & . & . & & . & C & $\mathbf{R}$ & $6-3,125$ \\
\hline 6 & & F & C & F & . & & . & & . & & $\mathrm{F}$ & & A & & $6-5,50$ \\
\hline $10-4,50$ & $\mathbf{R}$ & $\mathrm{F}$ & 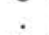 & $\mathrm{F}$ & . & . & 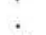 & $\therefore$ & . & . & C & . & $\mathrm{F}$ & $\dot{F}$ & $10-4,50$ \\
\hline $15-3,125$ & $\mathbf{R}$ & $\mathrm{F}$ & $\mathrm{F}$ & C & . & . & F & & . & $\mathbf{R}$ & . & . & & . & $15-3,125$ \\
\hline $16-4,50$ & . & $\mathrm{F}$ & $\mathrm{F}$ & C & . & : & 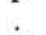 & . $\mathrm{C}$ & . & $\mathrm{F}$ & : & . & C & . & $16-4,50$ \\
\hline $17-3,50$ & & $\mathrm{~F}$ & C & A & & & F & & . & & & & A & & $17-3,50$ \\
\hline $19-3,123$ & $\mathbf{R}$ & . & C & & . & . & . & . C & . & F & $\mathbf{R}$ & . & C & . & $19-3,123$ \\
\hline $20-4,125$ & $\mathbf{R}$ & $\mathbf{R}$ & $\mathbf{R}$ & F & & & & & . & $\mathrm{F}$ & c. & . & & & $20-4,125$ \\
\hline $23-1,50$ & . & R & $\ddot{A}$ & F & . & . & & . $\mathrm{F}$ & . & C & F & . & C & $\mathbf{R}$ & $23-1,50$ \\
\hline $28-2,125$ & & . & $\mathbf{R}$ & & & . & & & & F & F & . & & & $28-2,125$ \\
\hline $32-2,50$ & $\mathbf{R}$ & F & A & A & $\mathbf{R}$ & . & $\mathbf{R}$ & . & & F & $\mathbf{R}$ & . & A & $\mathbf{R}$ & $32-2,50$ \\
\hline $33-1,50$ & . & $\mathrm{F}$ & A & . & & . & $\mathrm{F}$ & : & . & $\mathbf{R}$ & $\mathrm{F}$ & . & A & $\mathrm{F}$ & $33-1,50$ \\
\hline $34-6,125$ & $\mathrm{R}$ & C & A & A & R & . & . & . & & C & . & . & A & . $\mathbf{R}$ & $34-6,125$ \\
\hline
\end{tabular}

Table 8. Total ranges of nannofossils found in selected intervals at Hole 644A.

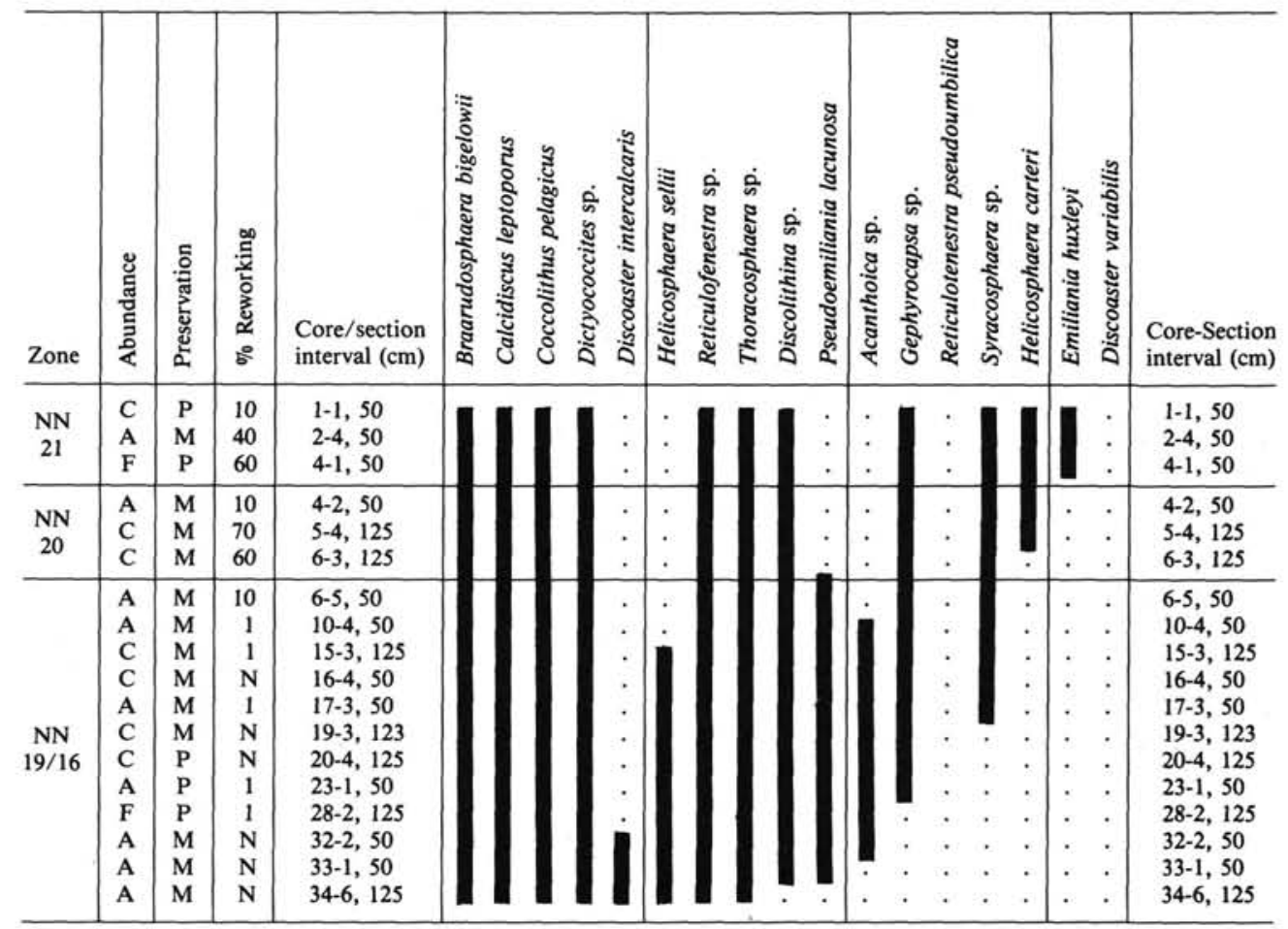

(Fig. 2). Thus, a gradient of productivity of the Norwegian Current extends from the landward to seaward sites. The surface currents' effect on nannofossil productivity decreases oceanward as the Norwegian Current waters diminish in extent.

Reworked specimens of older nannofossils are present throughout lithologic Unit I but become more abundant in the Quaternary than the Pliocene. The reworking consists primarily of
Cretaceous nannofossils but Paleogene and early Neogene redeposited species were also found to a lesser extent. Redeposited Cretaceous species often comprise up to 90 to $100 \%$ of the total nannofossil assemblage, while Paleogene species usually comprise much less than $10 \%$. Reworking is usually negligable in the interglacial intervals, but is much more pronounced in the glacial deposits. 


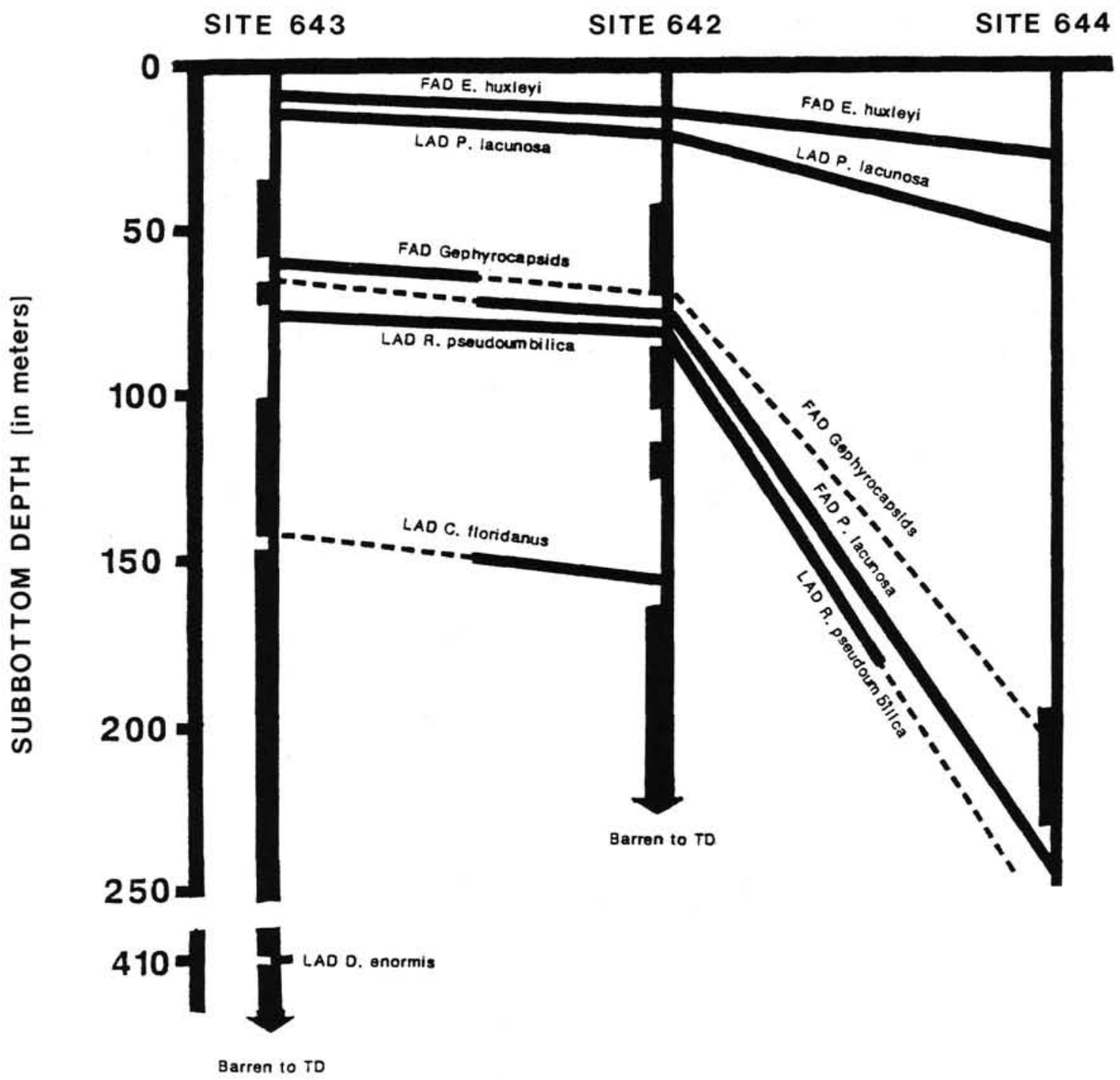

Figure 1. Correlation of the nannofossil occurrences of Sites 643,642 , and 644 . FAD $=$ First appearance datum. LAD $=$ Last appearance datum. Thick lines are extensive barren intervals.

The sediments as a general rule contain relatively few calcareous nannofossils and those that are present are of low diversity. There are, however, a few intervals with a notable abundance of nannofossils. Low abundances suggest relatively low water temperatures, with the nannofossil-rich oozes possibly reflecting relatively warmer water influxes. The interglacial sediments occasionally contain coccolith oozes with abundant yet low-diversity assemblages. Late-middle Miocene intervals show a slight increase in diversity. Both the Quaternary as well as the upper Miocene nannofossil-rich intervals contain many whole, intact coccospheres indicating little postdepositional disturbance from bioturbation.

The sediments at Site 644 , as a general rule, contain greater abundance, preservation, and diversity than at the deeper water Sites 642 and 643, possibly showing the influence of the relatively warmer Norwegian Current at Site 644 . But, on a global comparison, the abundance and diversity are still characterized by typical high-latitude, cold-water species.

\section{North Atlantic Correlations}

To better understand the geographic controls on nannofossil distribution and the difficulties of applying the standard low- latitude nannofossil zonations in the Norwegian-Greenland Sea, a latitudinal traverse of different sites is shown in Figure 3 and Table 9. The traverse is located in the North Atlantic from latitudes $30^{\circ} \mathrm{N}(\operatorname{Leg} 82), 56^{\circ} \mathrm{N}(\operatorname{Leg} 81), 58^{\circ} \mathrm{N}(\operatorname{Leg} 12)$, and finally the Vøring Margin at $68^{\circ} \mathrm{N}$ (Leg 104).

DSDP Leg 82 drilled in the North Atlantic between $30^{\circ}$ and $40^{\circ} \mathrm{N}$. The nannofossil biostratigraphy, as compiled by Bukry (1985) and Parker et al. (1985), contains essentially the full suite of zonal markers for the Neogene. The only exception is the absence of $\mathrm{CN} 10 \mathrm{~b}$ and $\mathrm{CN10c}$ due to a lower Pliocene hiatus. The area is not lacking in discoasters, ceratoliths, sphenoliths, or any of the other zonal markers used in the zonation of Okada and Bukry (1980).

DSDP Leg 81 is located north of Leg 82 , at a latitude of approximately $56^{\circ} \mathrm{N}$. Hole $552 \mathrm{~A}$ was the most complete and leastdisturbed upper Neogene sedimentary record yet obtained from the high-latitude North Atlantic at that time. Backman (1984) compiled the nannofossil biostratigraphy of the area and found that at this latitude certain marker fossils were diachronous or too sparse to be used to correlate with lower latitudes. Studies of the disappearances of Pliocene discoasters, which generally prefer warmer waters, have been carried out (Backman and 


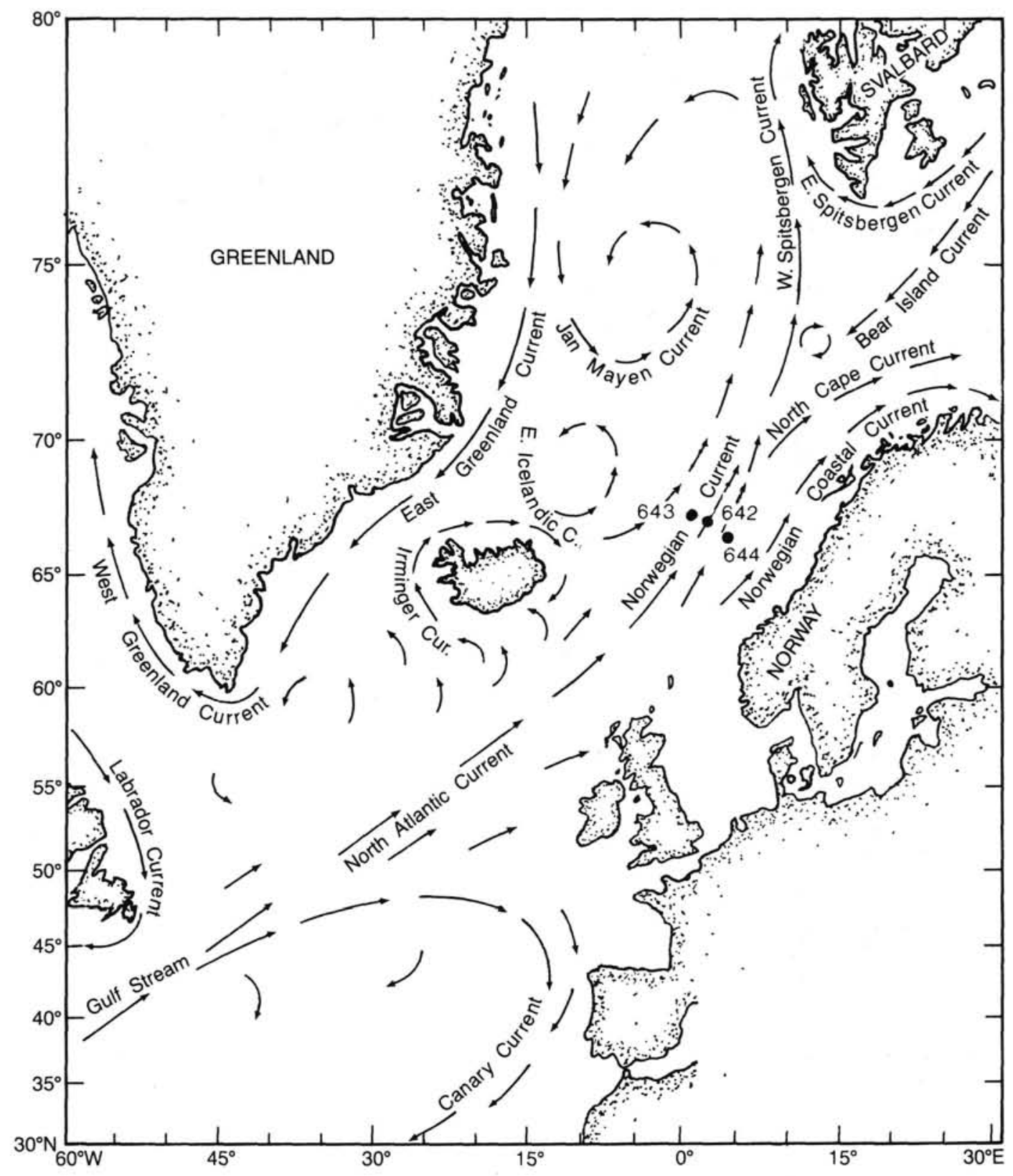

Figure 2. Present-day surface current patterns in the North Atlantic and Norwegian-Greenland Sea (based on Kellogg, 1975).

Shackleton, 1983) to help determine whether these disappearances represent genuine extinctions or only reflect migratory events. Backman (1984), using Hole 552A, interpreted Discoaster surculus as disappearing $0.1 \mathrm{~m} . \mathrm{y}$. before its Pacific extinction age. D. tamalis appears to have a slightly younger last occurrence in Hole 552A than in the low-latitude Pacific. D. pentaradiatus could be synchronous or could disappear 0.05 m.y. prior to its Pacific age, but the data gathered about the extinction age of $D$. pentaradiatus are not sufficient to settle this question. As mentioned previously, the extinction of Helicosphaera sellii has also been determined to be diachronous with latitude by Backman and Shackleton (1983). H. sellii is a zone marker for the Pleistocene zonation of Gartner (1977).

The extinction of Discoaster brouweri was originally used as a zonal marker in Leg 12 (Bukry 1972). However, Backman (1979) believes that $D$. brouweri, with optimum living conditions in low latitudes, actually disappeared from this high north- ern latitude site before its low-latitude extinction. The LAD $D$. brouweri at Site 116 is due to biogeographic response to changing environmental conditions and does not represent the true extinction level. Thus $D$. brouweri is not a useful datum for the northern North Atlantic in the Leg 12 study area.

The zonation for Site 116 is similar to that of Leg 81 because the sites are located relatively close to each other, but there are differences as the higher latitude is approached. Generally, discoasters and ceratoliths are more rare in the high-latitude assemblages than in mid- and low latitudes. However, enough discoasters and ceratoliths were found in Leg 81 sediments to determine a few zonal boundaries. During Leg 12 (at Site 116), some discoasters and ceratoliths were still found, but even fewer than for Leg 81 , thus eliminating a few more zones.

Leg 104 completes the south-to-north latitudinal cross section of the North Atlantic. Leg 104 sediments were totally lacking in ceratoliths and stratigraphically important discoasters. 


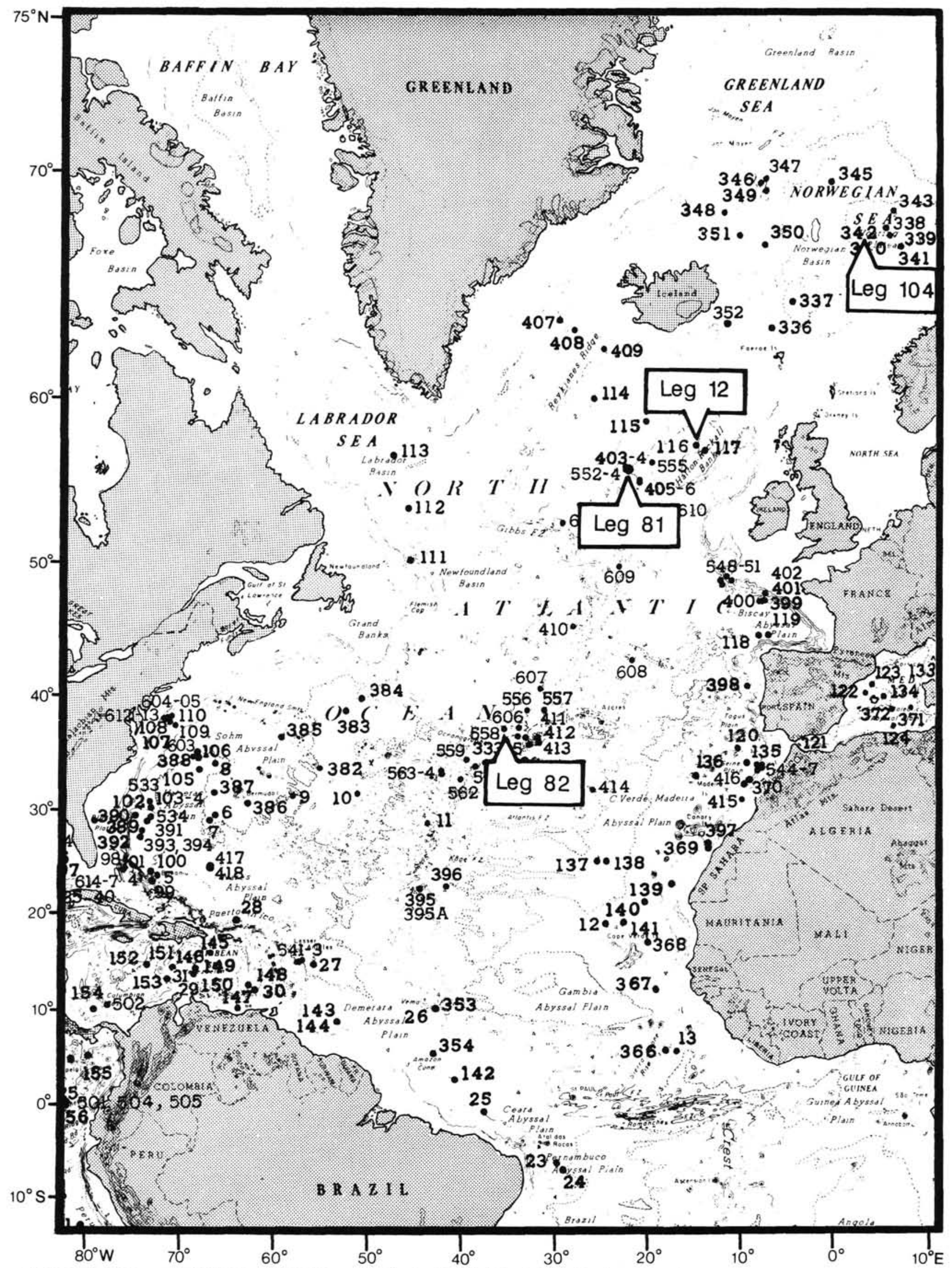

Figure 3. Location map of DSDP and ODP Legs used in the North Atlantic latitudinal cross section. 
Table 9. Nannofossil zones present in Legs 82, 81, 12, and 104 compared with the Okada and Bukry (1980) and Martini (1971) standard low-latitude zonal schemes (based on Martini and Müller, 1986).

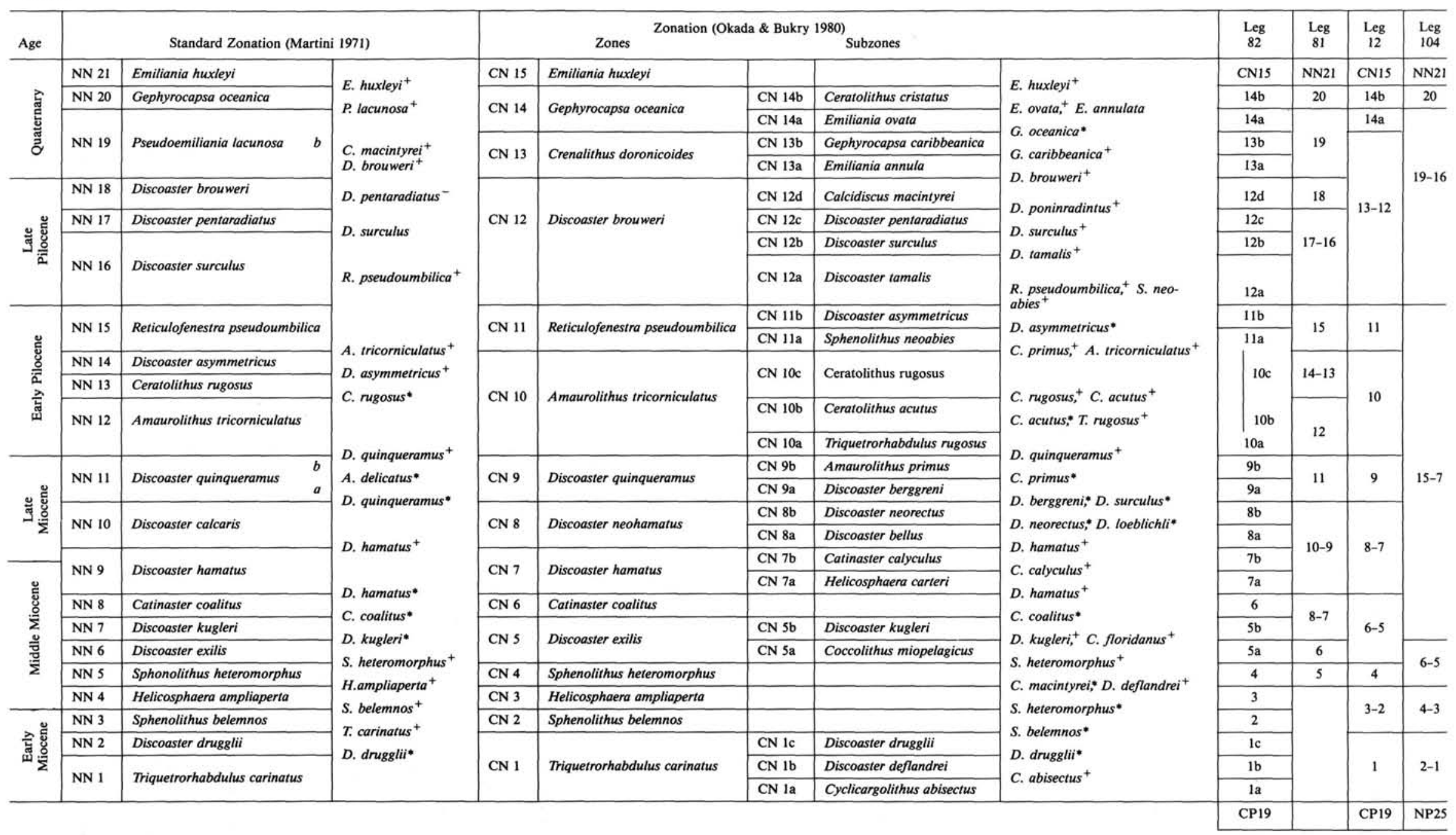


Only eight nannofossil zones could be differentiated in the Norwegian-Greenland Sea compared to the thirty zones and subzones distinguished at the Leg 82 sites to the south for the upper Oligocene to Holocene interval.

\section{REWORKED NANNOFOSSILS}

The Quaternary and upper Pliocene sediments of Leg 104 represent alternating cycles of glacial and interglacial deposition. The interglacial sediments consist of light-colored, carbonate-rich marine sandy muds, often nannofossil-rich. The glacial deposits consist of dark carbonate-poor glacial muds with dropstones. Generally these glacial deposits contain few, if any, Pliocene or Quaternary nannofossils deposited in situ. However, reworked Cretaceous and Paleogene nannofossils are often common. The abundance of the reworked nannofossils is cyclic in nature, varying from $100 \%$ to less than $1 \%$ of the total assemblage.

In the glacial deposits, it is often difficult to tell if the surface waters were sufficiently productive to support the deposition of in-situ nannofossils. This is due to the fact that many of the taxa found have long ranges which encompass ages from Cretaceous (e.g., Braarudosphaera bigelowii) or early Cenozoic (e.g., Coccolithus pelagicus and small reticulofenestrids) to present. The above species also are relatively dissolution resistant, which makes it difficult to interpret the abundance of reworked nannofossils. It is necessary to look at other Quaternary and upper Pliocene nannofossils, such as the gephyrocapsids, to determine whether the surface waters were productive enough at the time of deposition to deposit an in-situ assemblage along with the older, reworked nannofossils.

\section{Data}

To help pinpoint a possible age and source for the reworked Cretaceous nannofossils, three smear slides from the glacial intervals, where most of the reworking occurs, were examined. Three hundred and fifty-four Cretaceous nannofossils from glacial sediments were counted, and the taxa identified are shown in Table 10.

The stratigraphic distribution of some of these Cretaceous nannofossils is shown in Table 11 (based on Thierstein, 1976). All of the nannofossils found have ranges which, at least in part, are found in Maastrichtian deposits. In an effort to determine a more precise age for the Cretaceous nannofossils, various zonal schemes compiled by several authors have been applied (Table

Table 10. Absolute abundance of reworked taxa encountered in glacial intervals.

\begin{tabular}{lrrrr}
\hline & \multicolumn{4}{c}{ Hole 644A Core-Sect.-Int. } \\
\cline { 2 - 5 } \multicolumn{1}{c}{ Taxa Present } & $1-6-50$ & $5-3-125$ & $8-1-30$ & TTL \\
\hline Watznaueria spp. & 43 & 30 & 47 & 120 \\
Prediscosphaera cretacea & 15 & 13 & 45 & 73 \\
Micula stauropora & 6 & 5 & 20 & 31 \\
Eiffelithus turriseiffeli & 8 & 7 & 10 & 25 \\
Zygodiscus diplogrammus & 3 & 5 & 17 & 25 \\
Cribrosphaerella ehrenbergi & - & 2 & 12 & 14 \\
Chiastozygus litterarius & - & - & 11 & 11 \\
Vagalapilla octoradiata & 1 & 2 & 7 & 10 \\
Bronsonia spp. & 1 & 1 & 7 & 9 \\
Nephrolithus frequens & 1 & 1 & 6 & 8 \\
Tetralithus obscurus & 1 & 3 & 2 & 6 \\
Tranlolithus orionatus & 2 & 1 & 3 & 6 \\
Lucianorhabdus cayeuxii & 4 & - & 1 & 5 \\
Kamptnerius magnificus & - & - & 5 & 5 \\
Microrhabdulus decoratus & - & - & 3 & 3 \\
Eiffellithus trabeculatus & - & 2 & - & 2 \\
Cretarhabdus angustiforatus & - & - & 1 & 1 \\
Total & $\overline{72}$ & 197 & 354 & 85 \\
\hline
\end{tabular}

12). Unfortunately, most of the zonal markers for these schemes are absent. Only one marker from the Campanian to Maastrichtian interval, Nephrolithus frequens, was present among the redeposited species. The presence of $N$. frequens, however, suggests an uppermost Maastrichtian age, although other specimens could possibly have come from older strata. Although all the other Cretaceous markers found occur throughout the Campanian and Maastrichtian, their FAD's are earlier. This presents a problem when trying to pinpoint the age of the sources of the reworking, if such a specific age can, in fact, be determined.

The reason for the missing Campanian and Maastrichtian marker fossils could be the ecologic exclusion of the nannofossils from the source area due to unfavorable environmental conditions at the time of original deposition. This will be discussed subsequently.

Figure 4 (Ziegler, 1982) shows the known distribution of calcareous deposits of Cenomanian to Danian age. The Leg 104 sites are located slightly north of the area mapped, but the calcareous deposits are much less extensive to the north. The mapped areas of calcareous deposition, therefore, delineate possible source areas for the reworked Cretaceous nannofossils. The most extensive deposits of known calcareous material occur in the North Sea-Denmark area. Less extensive deposits are found on the Faeroe high and small deposits also occur along the shelf off Norway. These three areas are the most likely sources for the Cretaceous nannofossils reworked into the glacial deposits.

Areas further south can be eliminated as a source by applying biogeographic barriers for the Cretaceous nannofossils found. Thierstein (1981) studied upper Campanian to lower Danian nannofossil assemblages from all over the world. He concluded that Late Cretaceous bioprovincialism was strongly dependent on paleolatitude. Thierstein studied the relative abundance distribution of 54 Late Cretaceous nannofossil taxa. He plotted the nannofossils with recognizable distribution patterns on maps showing their paleolatitudinal occurrences during the Late Cretaceous. Figures 5 and 6 show the dominant taxa with recognizable distribution patterns for upper Campanian through upper Maastrichtian assemblages, and their global biogeographic distributions are contoured on these paleogeographic maps. Not shown on his maps are occurrences that make up less than $2 \%$ of the assemblages. For purposes of the present study, we will disregard occurrences of less than $2 \%$ (which correspond to less than seven out of the 354 nannofossils identified) of the total glacially reworked nannofossils. By relating the taxa found on Leg 104 to those in Thierstein's study, an estimate can be made of the latitudinal limit for the Cretaceous sources.

Figure 5 displays the geographic distribution of some of the taxa actually encountered in Leg 104 glacial sediments. Although found in low numbers, Nephrolithus frequens is of great value to the study. This taxon provides an accurate age determination because it is confined to uppermost Maastrichtian deposits. Also, it is encountered in appreciable numbers only in high-latitude locations, therefore it marks a southern limit for the source beds of Cretaceous reworking.

Figure 6 shows the distribution of some of the taxa not encountered in Leg 104 material. Lithraphidites quadratus is shown to have a North Atlantic occurrence limit of approximately $45^{\circ}$ $50^{\circ}$ north latitude. Since this taxon is not encountered in Leg 104 cores, the sediments containing it are not the source for the reworking. Thus, by using nannofossil provincialism during Cretaceous time the source for the reworked material can be further delineated. Figure 7 summarizes the geographic distribution of selected Cretaceous taxa not present in Leg 104 sediments, while Figure 8 shows the distribution of the taxa present. The source for the reworking must originate from the areas where the taxa in Figure 8 occur, but not the areas where the 
Table 11. Stratigraphic distribution of selected Cretaceous nannofossils encountered in Leg 104 glacial sediments (based on Thierstein, 1976).

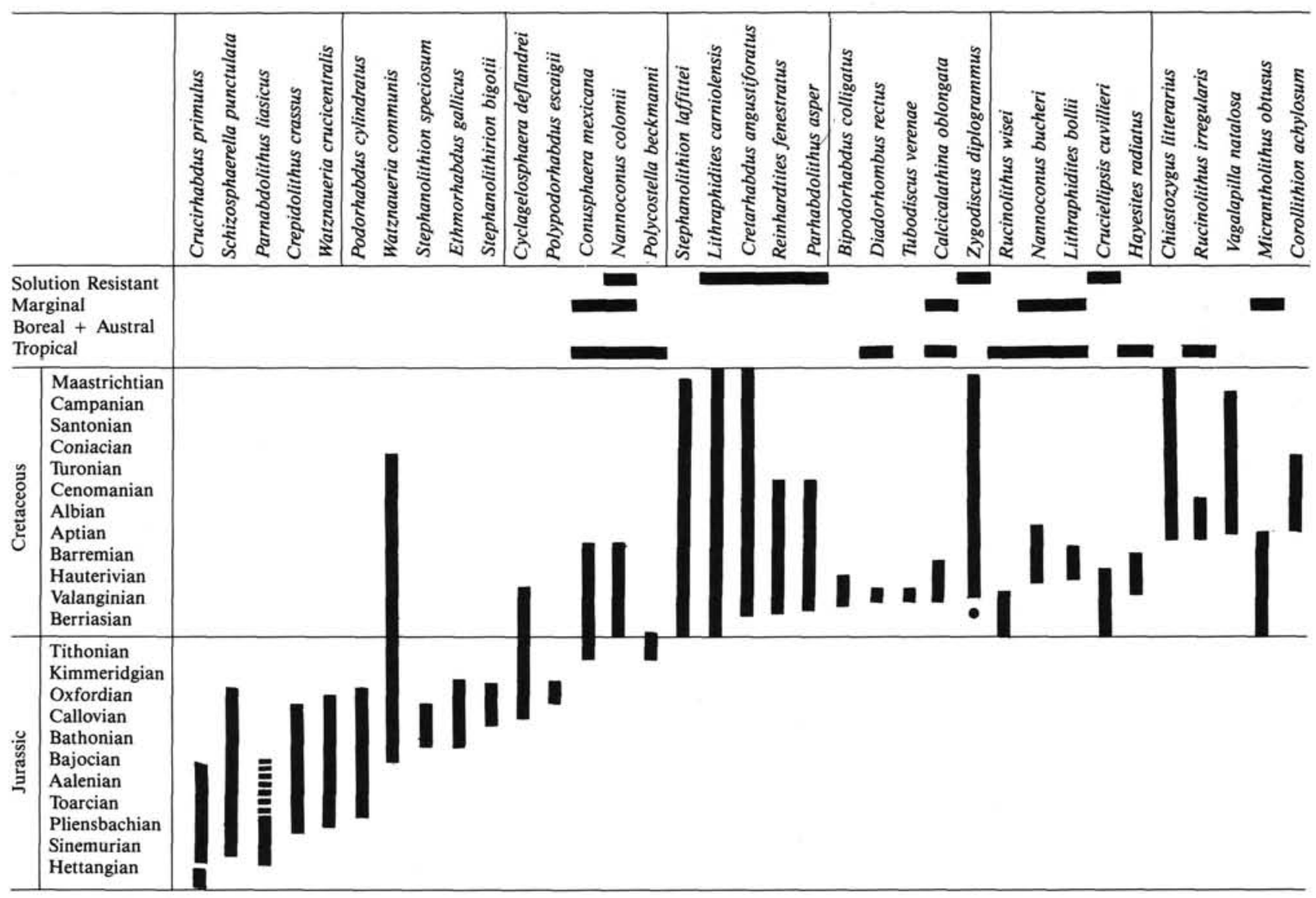

taxa in Figure 7 occur. Thus, Figures 7 and 8 display the geographic limits, and thereby possible source areas, for the reworked Cretaceous nannofossils actually found in the Tertiary of Leg 104.

Before discussing further the possible sources for the reworked nannofossils encountered in the glacial deposits of Leg 104 , we must consider the climatic variability of the area during the late Cenozoic. High-latitude glaciations during the late Quaternary dramatically changed sea-surface conditions in polar seas relative to those found in the present day (Corliss, et al., in press). Three general climatic regimes have existed since the onset of glaciation: glacial, intermediate, and interglacial. These three regimes all show unique depositional patterns in response to the Northern Hemisphere glaciations. Many detailed studies have been compiled relating to the most recent glacial cycles (Kellogg, 1975; Kellogg, 1980; Ruddiman and McIntyre, 1979; Jansen and Bjørklund, 1985; and others). The major difference between the glacial and interglacial periods is the absence or severe reduction of the warm Norwegian Current water entering the region from the North Atlantic during glacials (Fig. 9).

During the last glacial interval at $18 \mathrm{ka}$, the Norwegian Sea was generally completely covered with sea ice (Fig. 10). But, during the summer months, open water or looser pack ice could have existed south of $71^{\circ} \mathrm{N}$ in the central Norwegian Sea (Kellogg, 1980). Winter temperatures were $0.0^{\circ} \mathrm{C}$ or less and summer temperatures ranged between 4.6 and $5.4^{\circ} \mathrm{C}$. The last interglacial episode was similar to present ice-free conditions (Fig. 10). The intermediate regime 82 ka represents an intermediate regime between these glacial and interglacial conditions. Seasonal ice cover existed in the southern part of the Norwegian Sea. The Norwegian Current was not present with its modern characteris- tics, but a weak flow of relatively warm water most likely entered the southern Norway Basin from the North Atlantic. Ruddiman and McIntyre (1979) showed that during the first half of the last full interglacial-glacial cycle, the subpolar North Atlantic from $40^{\circ}$ to $60^{\circ} \mathrm{N}$ maintained relatively warm sea-surface temperatures. This allows for an interglacial ocean alongside a glacial landmass. Thus, the Norwegian Current could potentially carry icebergs to the Norwegian-Greenland Sea during these times.

\section{Discussion}

By taking into account the previously discussed comparison of the bioprovincialism of the Cretaceous nannofossils, the known areas of Cretaceous carbonate deposition, and the climatic regimes of the times, it is possible to narrow down the geographic limits for the source of the reworking. Three main areas exist as the potential source location of the Cretaceous reworked nannofossils found on the Vøring Plateau.

One such area is to the south of the Vøring Plateau. Subsea outcrops of Cretaceous marls and possibly chalks could be exposed along faults in the area (K. Perch-Nielsen, written commun., 1986). Material from these exposures could be reworked into the Vøring Plateau sediments. However, the nature of the sediments that contain most of the reworked Cretaceous nannofossils indicate that these sediments were deposited by advancing sea ice and/or floating ice blocks that would have little affect on the exposed Cretaceous beds in the deeper water.

Another possibility is reworking from the shelf near the Leg 104 sites. Seismic sections show that Quaternary sediments locally overlie Paleocene and Upper Cretaceous sediments (A. Moe, written commun., 1986). Pockets of these exposed older 
Table 11 (continued).

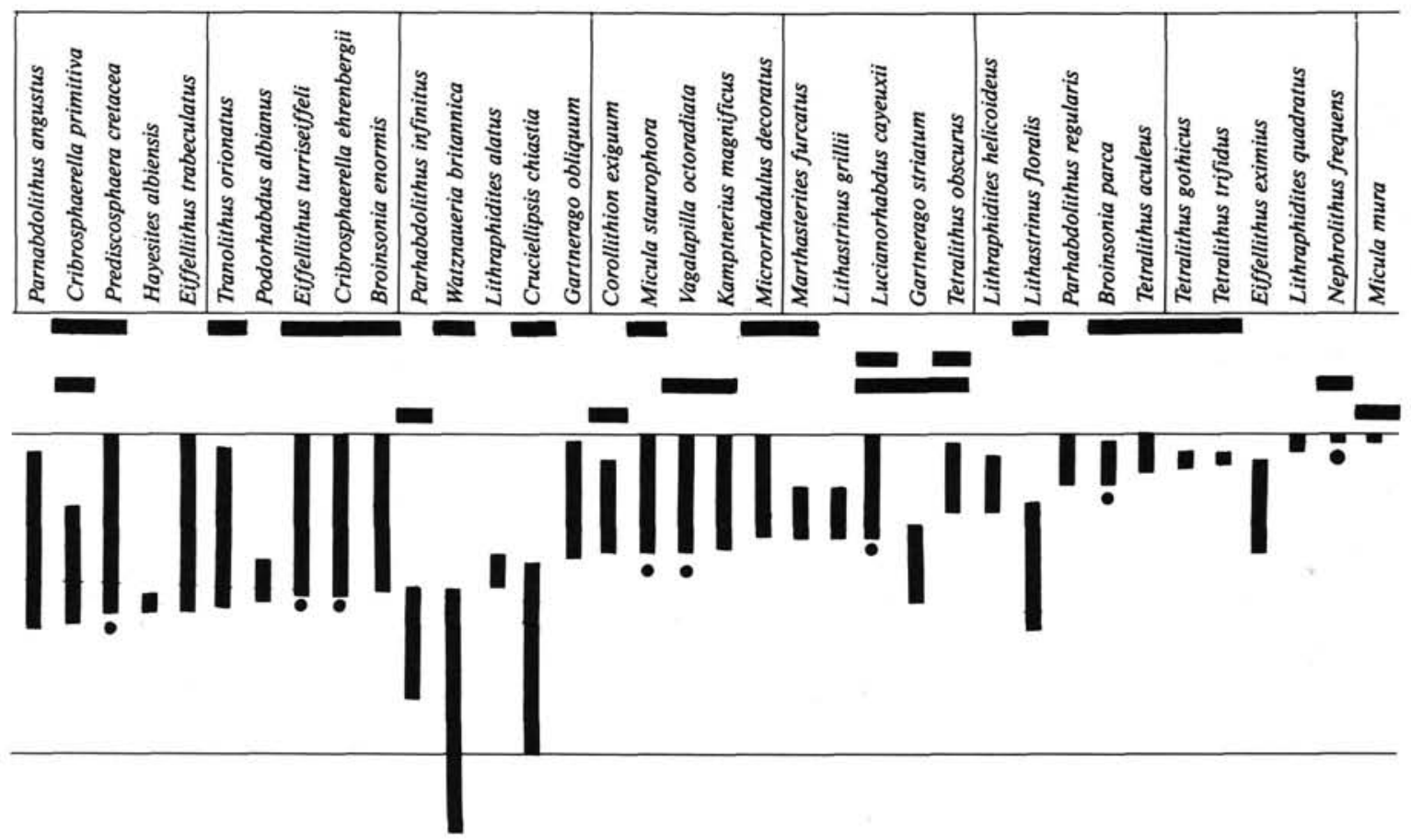

sediments could be reworked into the upper Pliocene to Quaternary deposits during the glacial intervals, especially with the help of concomitant lowered sea levels. However, a problem exists with the Cretaceous source exposures in this area. At such a high latitude, only a few scattered areas of carbonate deposition existed during Cretaceous times (Fig. 4). These pockets of Cretaceous carbonate deposition could very well have been reworked to some extent into the glacial sediments, but it is unlikely that these small exposures, which did not contain a rich nannofossil source, could account for the large amounts of Cretaceous nannofossils found in Leg 104 sediments. A richer source of Campanian and Maastrichtian nannofossils is implied.

A third possible source for the reworked nannofossils is from icebergs originating in the North Sea-Denmark area, especially in the northern North Sea and in northern Denmark where only a thin cover of Quaternary sediments existed on top of the Cretaceous strata (Ziegler, 1982). This area is an ideal source area due to its extensive chalk deposits of Campanian to Maastrichtian age. As continental ice sheets began to develop, glaciers would have moved out of the North Sea-Denmark area towards the Norwegian Sea. During the times when the NorwegianGreenland Sea was not completely ice-covered, individual icebergs would have carried sediments out of the North Sea area to the west. Because the Norwegian-Greenland Sea was not entirely ice-covered at this time, the Norwegian Current would still have been actively flowing from south to north past the North Sea, although not as actively as during the true interglacials. The icebergs from the North Sea-Denmark area would have been carried farther north as they merged with the Norwegian
Current. As the floating icebergs melted in the relatively warm Norwegian Current waters, ice-rafted debris containing Campanian and Maastrichtian nannofossils from the North Sea-Denmark source would have been deposited.

The source of the reworked nannofossils found in the Norwegian-Greenland Sea is possibly derived from a combination of the above three stated source areas. During the summer months of the glacial periods and during the intermediate stages between glacial and interglacial regimes, ice-rafted material from the nannofossil-rich Cretaceous strata of northern North SeaDenmark area was probably deposited on the Vøring Plateau. This would have been the primary source of the reworking. Minor reworking from the shelf or exposed faults could have brought additional Cretaceous nannofossils to the area, but because no nannofossil-rich source deposits were involved, they cannot be the major source.

\section{CONCLUSION}

ODP Leg 104 drilled and recovered cores from eight holes at three sites on the Vøring Plateau in the Norwegian-Greenland Sea. An essentially complete sedimentary section was obtained and contains calcareous nannofossils from uppermost Oligocene to Holocene sediments.

Due to poor high-latitude environmental conditions, the nannofossil assemblages recovered contain low abundances and diversities when compared to low-latitude assemblages. The standard low-latitude nannofossil zonal markers of the Neogene, the ceratoliths, discoasters, and sphenoliths, are mostly missing in the Norwegian-Greenland Sea sediments, making biostrati- 
Table 12. Various Cretaceous nannofossil zonal schemes compiled by several authors (from Perch-Nielsen, 1985).

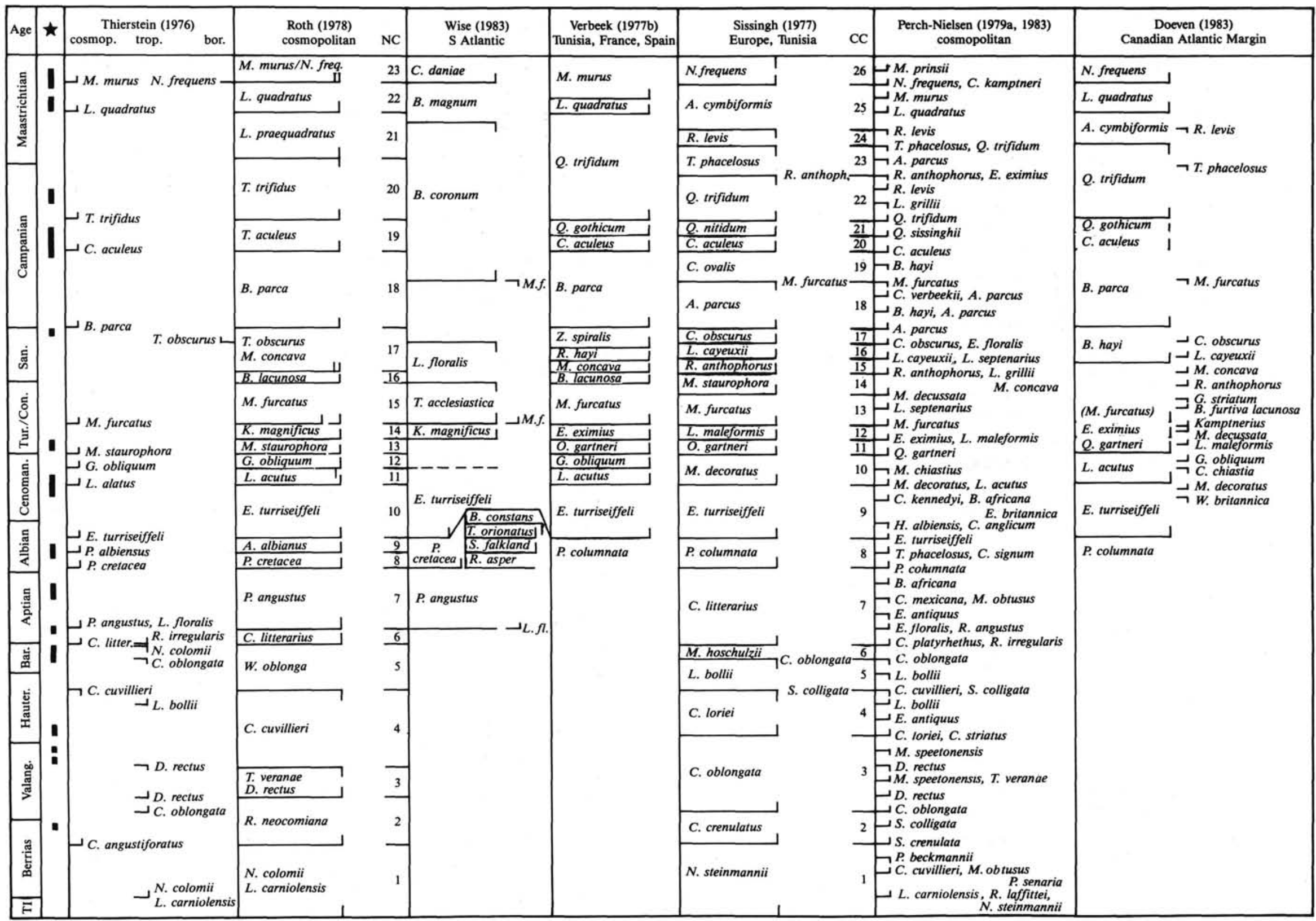




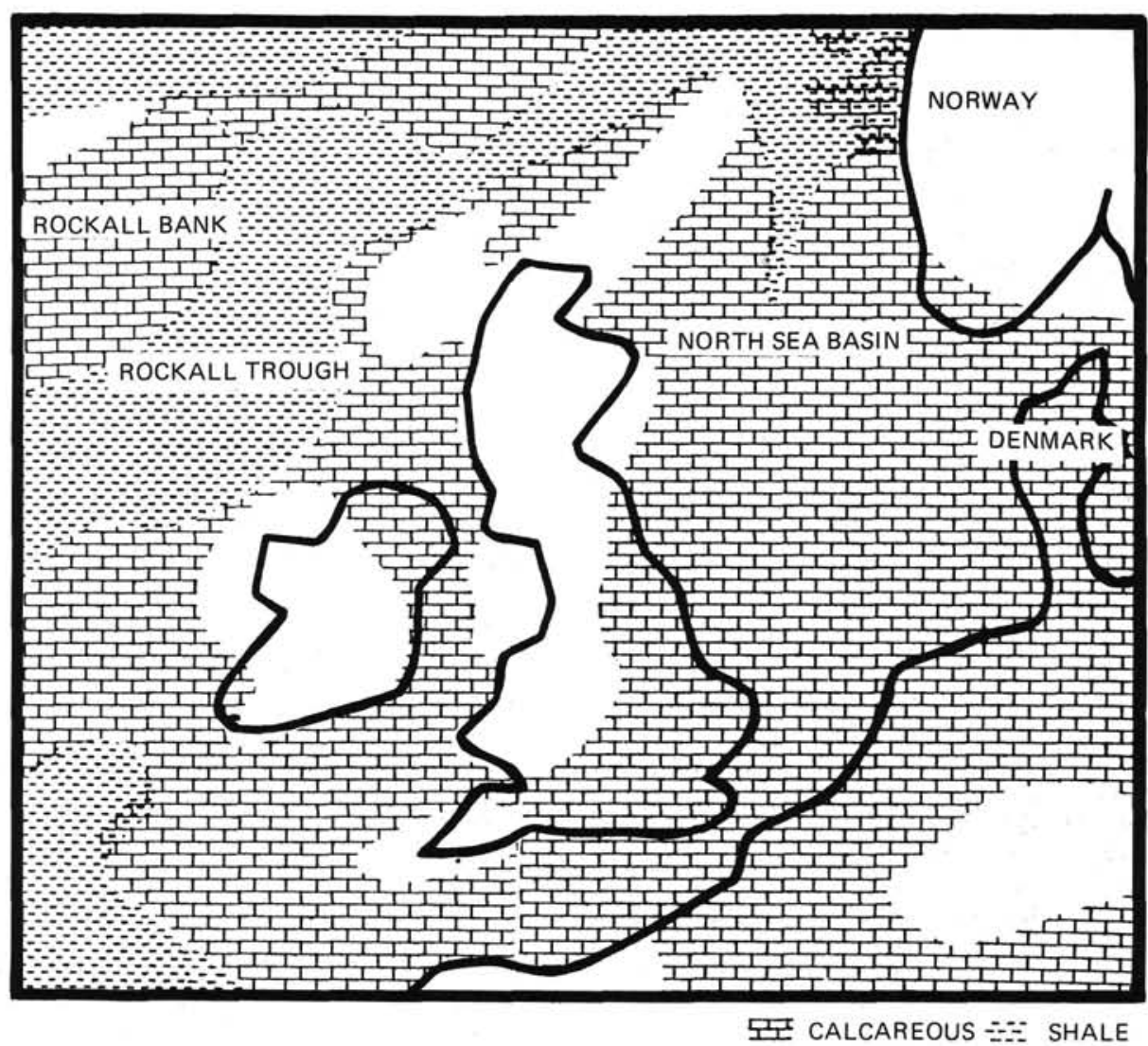

Figure 4. Distribution of sediments deposited in the North Atlantic and North Sea during Cenomanian-Danian (from Ziegler, 1982).

graphic interpretations difficult. Since latest Oligocene time, eight nannofossil zones can be differentiated compared to approximately 30 zones for the same interval in the lower latitude North Atlantic.

The sediments deposited since the first appearance of icerafted detritus represent glacial conditions. Dark-colored, carbonate-poor glacial sediments with ice-rafted debris present are interlayered with light-colored, carbonate- (and nannofossil-) rich interglacial sediments. The interglacial deposits contain abundant nannofossils and represent influxes of relatively warm Norwegian Current waters. The glacial deposits represent relatively cold times with solid ice cover or icebergs present in the Norwegian-Greenland Sea. The glacial deposits contain few, if any, in-situ nannofossils, but reworked Cretaceous species with minor reworked Paleogene species and older Neogene nannofossils are often common.

The age of the reworked Cretaceous nannofossils is Campanian to Maastrichtian. The presence of $N$. frequens suggests a source of latest Maastrichtian age, but more than one source could be contributing to the reworked nannofossils found on the Vøring Plateau. Three possible sources for the common reworked nannofossils found are: (a) exposed Cretaceous deposits along the shelf near Norway; (2) exposed Cretaceous outcrops along faults in the area; and/or (3) the northern North SeaDenmark area. The relative abundances of the reworked assemblage suggest that the primary source was ice-rafting from the northern North Sea-Denmark area.

\section{REFERENCES}

Arkhangelsky, A. D., 1912. Upper Cretaceous deposits of east European Russia. Mater. Geol. Russ., 25:1-631.
Backman, J., 1978. Late Miocene-early Pliocene nannofossil biochronology and biogeography in the Vera Basin, SE Spain. Acta Univ. Stockholm Contrib. Geol., 32:93-114.

Backman, J., 1979. Pliocene biostratigraphy of DSDP Sites 111 and 116 from the North Atlantic Ocean and the age of Northern Hemisphere glaciation. Acta Univ. Stockholm Contrib. Geol., 32:115-137.

Backman, J., 1980. Miocene-Pliocene nannofossils and sedimentation rates in the Hatton-Rockall basin, Atlantic Ocean. Acta Univ. Stockholm Contrib. Geol., 3:1-91.

Backman, J., 1984. Cenozoic calcareous nannofossil biostratigraphy from the north-eastern Atlantic Ocean Deep Sea Drilling Project Leg 81. In Roberts, D. G., Schnitker, D., et al., Init. Repts. DSDP, 81: Washington (U.S. Govt. Printing Office), 403-428.

Backman, J., and Shackleton, N. J., 1983. Quantitative biochronology of Pliocene and early Pleistocene calcareous nannoplankton from the Atlantic, Indian, and Pacific oceans. Mar. Micropaleontol., 8: 141-170.

Black, M., 1967. New names for some coccolith taxa. Proc. Geol. Soc. London, 1640:139-145.

Black, M., 1971a. Coccoliths of the Speeton clay and Sutterby marl. Proc. Yorkshire Geol. Soc., 38:381-424.

Black, M., and Barnes, B., 1959. The structure of coccoliths from the English chalk. Geol. Mag., 96:321-328.

Bramlette, M. N., and Martini, E., 1964. The great change in calcareous nannoplankton fossils between the Maestrichtian and Danian. Micropaleontology, 10:291-322.

Bramlette, M. N., and Riedel, W. R., 1954. Stratigraphic value of discoasters and some other microfossils related to Recent coccolithophores. J. Paleontol., 28:385-403.

Bramlette, M. N., and Sullivan, F. R., 1961. Coccolithophorids and related nannoplankton of the early Tertiary in California. Micropaleontology, 7:129-174.

Bramlette, M. N., and Wilcoxon, J. A., 1967. Middle Tertiary calcareous nannoplankton of the Cipero section, Trinidad, W. I. Tulane Stud. Geol., 5:93-131. 
Brönnimann, P., and Stradner, H., 1960. Die Foraminiferen und Discoasteridenzonen von Kuba und ihr interkontinentale Korrelation. Erdoel-Z., 76:364-369.

Buchardt, B., 1978. Oxygen isotope paleotemperatures from the Tertiary period in the North Sea area. Nature, 275:121-123.

Bukry, D., 1969. Upper Cretaceous coccoliths from Texas and Europe. Univ. Kansas Paleontol. Contrib., 51 (Protista 2):1-79. 1971. Cenozoic calcareous nannofossils from the Pacific Ocean. San Diego Soc. Nat. Hist., Trans., 16:303-327.

1972. Further comments on coccolith stratigraphy, Leg 12, Deep Sea Drilling Project. In Laughton, A. S., Berggren, W. A., et al., Init. Repts. DSDP, 12: Washington (U.S. Govt. Printing Office), 1071-1083.

1973. Low-latitude coccolith biostratigraphic zonation. In Edgar, N. T., et al., Init. Repts. DSDP, 15: Washington (U.S. Govt. Printing Office), 685-703.

1985. Mid-Atlantic Ridge coccolith and silicoflagellate biostratigraphy, DSDP Sites 558 and 563. In Bougault, H., Cande, S. C., et al., Init. Repts. DSDP, 82: Washington (U.S. Govt. Printing Office), 591-603.

Bukry, D., and Bramlette, M. N., 1969. Some new and stratigraphically useful calcareous nannofossils of the Cenozoic. Tulane Stud. Geol. Paleontol., 7:131-142.

Corliss, B. H., Martinson, D. G., Keffer, T., in press. Late Quaternary deep-ocean circulation. Geol. Soc. Am. Bull.

Deflandre, G., 1947. Braarudosphaera nov. gen., type d'un famille nouvelle de Coccolithophorides actuels à éléments composites. C. R. Séances Acad. Sci. Paris, 225:439-441.

1952. Classe des coccolithophorides. In Grasse, P. P. (Ed.), Traité de Zoologie, 1:439-470.

1959. Sur les nannofossiles calcaires et leur systematique. Rev. Micropaleontol., 2:127-152.

Deflandre, G., and Fert, C., 1954. Observations sur le Coccolithophorides actuels et fossiles en microscope ordinaire et électronique. Ann. Paleontol., 40:115-176.

Gardet, M., 1955. Contribution á l'étude des coccolithe des terrains Mésogènes de l'Algerie. Publ. Serv. Carte Geol. Algerie, Ser. 2, Bull. 5:477-550.

Gartner, S., Jr., 1967. Calcareous nannofossils from Neogene of Trinidad, Jamaica, and Gulf of Mexico. Univ. Kansas, Paleontol, Contrib., 29:1-7.

1968. Coccoliths and related calcareous nannofossils from upper Cretaceous deposits of Texas and Arkansas. Univ. Kansas, Paleontol. Contrib., 48, Protista 1:1-56.

1969. Correlation of Neogene planktonic foraminifera and calcareous nannofossil zones. Trans. Gulf Coast Assoc. Geol. Soc., 19:585-599.

, 1977. Calcareous nannofossil biostratigraphy and revised zonation of the Pleistocene. Mar. Micropaleontol., 2:1-25.

Gorka, H., 1957. Les coccolithophorides du Maestrichtien superieur de Pologne. Acta Paleontol. Pol., 2:235-284.

Gran, H. H., and Braarud, T., 1935. A quantitative study of the phytoplankton in the Bay of Fundy and the Gulf of Maine (including observations on hydrography, chemistry, and turbidity). J. Biol. Board Canada, 1:279-467.

Haeckel, E., 1894. Systematische Phylogenie der Protisten und Pflanzen: Berlin (Reimer).

Haq, B. U., 1966. Electron microscope studies on some upper Eocene calcareous nannoplankton from Syria. Stockholm Contrib. Geol., 15:23-27.

1976. Coccoliths in cores from the Bellinghausen abyssal plain and Antarctic continental rise. In Hollister, C. D., Craddock, C., et al., Init. Repts. DSDP, 35: Washington (U.S. Govt. Printing Office), 557-567.

Haq, B. U., and Berggren, W. A., 1978. Late Neogene calcareous plankton biochronology of the Rio Grande Rise (South Atlantic Ocean). J. Paleontol., 52:1167-1194.

Hay, W. W., Mohler, H. P., Roth, P. H., Schmidt, R. R., and Boudreaux, J. E., 1967. Calcareous nannoplankton zonation of the Cenozoic of the Gulf Coast and Caribbean-Antillean area, and transoceanic correlation. Trans. Gulf Coast Assoc. Geol. Soc., 17:428480.

Hay, W. W., Mohler, H. P., and Wade, M. E., 1966. Calcareous nannofossils from Nal'chik (northwest Caucasus). Eclog. geol. Helv., 59: 379-399. von Heck, S. E., 1979a. Bibliography and taxa of calcareous nannoplankton. Int. Nannoplankton Assoc. Newsl., AB1-5, A1-12, B1-27. , 1979b. Bibliography and taxa of calcareous nannoplankton. Int. Nannoplankton Assoc., Newsl., 1: AB VI, A13-28, B28-42. 1980a, Bibliography and taxa of calcareous nannoplankton. Int. Nannoplankton Assoc. Newsl., 2:5-34.

1980b. Bibliography and taxa of calcareous nannoplankton. Int. Nannoplankton Assoc. Newsl., 2:43-81.

1981a. Bibliography and taxa of calcareous nannoplankton. Int. Nannoplankton Assoc. Newsl., 3:4-41.

1981b. Bibliography and taxa of calcareous nannoplankton. Int. Nannoplankton Assoc. Newsl., 3:51-86. 1982a. Bibliography and taxa of calcareous nannoplankton. Int. Nannoplankton Assoc. Newsl., 4:7-50. 1982b. Bibliography and taxa of calcareous nannoplankton. Int. Nannoplankton Assoc. Newsl., 4:65-96.

1983. Bibliography and taxa of calcareous nannoplankton. Int. Nannoplankton Assoc. Newsl., 5:4-13.

Jafar, S. A., and Martini, E., 1975. On the validity of the calcareous nannoplankton genus Helicosphaera. Senckenbergiana lethaea, 56: 381-397.

Jansen, E., and Bjørklund, K. R., 1985. Surface ocean circulation in the Norwegian Sea 15,000 B.P. to present. Boreas, 14:243-257.

Kamptner, E., 1927. Beitrag zur Kenntnis adriatischer Coccolithophoriden. Arch. Protistenk., 58:173-184.

1943. Zur Revision der Coccolithineen-Spezies Pontosphaera huxleyi Lohm. Anz. Akad. Wiss. Wien, Math.- Naturw. Kl., 80:4349.

1963. Coccolithineen-Skelettreste aus Tiefseeablagerungen des Pazifischen Ozeans. Ann. Naturh, Mus. Wien., 66:139-204.

1967. Kalkflagellaten-Skelettreste aus Tiefseeschlamm des Südatlantischen Ozeans. Ann. Naturh. Mus. Wien, 71:117-198.

Kellogg, T. B., 1975. Late Quaternary climate changes in the Norwegian and Greenland Seas. In Bowling, S. A., and Weller, G. (Eds): Climate of the Arctic: College (Univ. of Alaska), 3-36.

1980. Paleoclimatology and paleo-oceanography of the Norwegian and Greenland seas: glacial-interglacial contrasts. Boreas, 9: 115-137.

Kennett, J. P., 1982. Marine Geology: New Jersey (Prentice- Hall, Inc).

Locker, S., 1967. Neue Coccolithophoriden (Flagellata) aus dem Alttertiär Norddeutschlands. Geologie (Berlin), 16:361-364.

Loeblich, A. R., Jr., and Tappan, H., 1966. Annotated index and bibliography of the calcareous nannoplankton, I. Phycologia, 5:81-216. 1968. Annotated index and bibliography of the calcareous nannoplankton, II. J. Paleontol., 42:584-598.

1969. Annotated index and bibliography of the calcareous nannoplankton, III. J. Paleontol., 43:568-588.

, 1970a. Annotated index and bibliography of the calcareous nannoplankton, IV. J. Paleontol., 44:558-574. $1970 \mathrm{~b}$. Annotated index and bibliography of the calcareous nannoplankton, V. Phycologia, 9:157-174.

1971. Annotated index and bibliography of the calcareous nannoplankton, VI. Phycologia, 10:315-339.

1973. Annotated index and bibliography of the calcareous nannoplankton, VII. J. Paleontol., 47:715-759.

Loeblich, A. R., Jr., and Tappan, H., 1978. The coccolithophorid genus Calcidiscus Kamptner and its synonyms. J. Paleontol., 52:1390-1392.

Lohmann, H., 1902. Die Coccolithophoridae, eine Monographie der Coccolithen-bildenden Flagellaten, zugleich ein Beitrag zur Kenntnis des Mittelmeerauftriebs. Arch. Protistenk., 1:89-165.

Manivit, H., 1971. Les nannofossiles calcaires du Crétace français (de l'Aptien au Danien). Essai de biozonation appuyée sur les stratotypes [Thèse]. Université de Paris.

Manivit, H., Perch-Nielsen, K., Prins, B., and Verbeek, J. W., 1977. Mid Cretaceous calcareous nannofossil biostratigraphy. Kon. Nederl. Akad. Wet., B80:169-181.

Martini, E., 1961. Nannoplankton aus dem Tertiär und der obersten Kreide von SW-Frankreich. Senckenbergiana lethaea, 42:1-32. 1965. Mid-Tertiary calcareous nannoplankton from Pacific deep-sea cores. In Whittard, W. F., and Bradshaw, R. B. (Eds.), Submarine Geology and Geophysics. Proc. 17th Symp. Colston Res. Soc.: London (Butterworths), 393-411. 1971. Standard Tertiary and Quaternary calcareous nannoplankton zonation. In Farinacci, A. (Ed.), Proc. II Planktonic Conference, Roma, 1970, 2:739-785. 
Martini, E., and Bramlette, M. N., 1963. Calcareous nannoplankton from the experimental Mohole drilling. Paleontology, 37:845-856.

Martini, E., and Müller, C., 1986. Current Tertiary and Quaternary calcareous nannoplankton stratigraphy and correlations. Newsl. Stratigr., 16:99-112.

McIntyre, A., 1970. Gephyrocapsa protohuxleyi sp. n., possible phyletic link and index fossil for the Pleistocene. Deep-Sea Res., 17: $187-190$.

McIntyre, A., Bé, A. W. H., and Preikstas, R., 1967. Coccoliths and the Pliocene-Pleistocene boundary. Prog. Oceanography, 4:3-25.

Miller, K., Aubry, M.-P., Khan, M., Mellilo, A., Kent, D., and Berggren, W., 1985. Oligocene-Miocene biostratigraphy, magnetostratigraphy, and isotope stratigraphy of the western North Atlantic. Geology, 13:257-261.

Müller, C., 1970. Nannoplankton-Zonen der unteren Meeresmolasse Bayerns. Geol. bavar., 63:107-118.

Müller, C., 1976. Tertiary and Quaternary calcareous nannoplankton in the Norwegian-Greenland Sea, DSDP, Leg 38. In Talwani, M., Udintsev, G., et al., Init. Repts. DSDP, 38: Washington (U.S. Govt. Printing Office), 823-841.

Murray, G., and Blackman, V. H., 1898. On the nature of the coccospheres and rhabdosphaeres. Philos. Trans. R. Soc. London, 190B: 427-441.

Okada, H., and Bukry, D., 1980. Supplementary modification and introduction of code numbers to the low-latitude coccolith biostratigraphic zonation (Bukry, 1973; 1975). Mar. Micropaleontol., 5:321325

Parker, M. E., Clark, M., and Wise, S. W. Jr., 1985. Calcareous nannofossils of DSDP Sites 558 and 563, North Atlantic Ocean: biostratigraphy and distribution of Oligocene braarudosphaerids. In Bougault, H., Cande, S. C., et al., Init. Repts. DSDP, 82: Washington (U. S. Govt. Printing Office), 559-589.

Perch-Nielsen, K., 1968. Der Feinbau und die Klassifikation der Coccolithen aus dem Maastrichtien von Dänemark. K. Dan. Vidensk. Selsk. Biol. Skr., 16:1-96. $42-46$.

1984a. Validation of new combinations. INA Newsletter, 6:

Perch-Nielsen, K., 1985. Cenozoic calcareous nannofossils. In Bolli, H. M., Saunders, J. B., and Perch-Nielsen, K. (Eds.), Plankton Stratigraphy: Cambridge (Cambridge University Press), 427-554.

Piveteau, J., 1952. Traité de Paléontologie, 1: Paris (Masson), 107-115.

Reinhardt, P., 1964. Einige Kalkflagellaten-Gattungen (Coccolithophoriden, Coccolithineen) aus dem Mesozoikum Deutschlands. Monatsber. Dt. Akad. Wiss. Berlin, 6:749-759.

Reinhardt, P., 1965. Neue Familien für fossile Kalkflagellaten (Coccolithophoriden, coccolithineen). Monatsber. Dt. Akad. Wiss. Berlin, 7:30-40.

Reinhardt, P., 1966a. Zur Taxionomie und Biostratigraphie des fossilen Nannoplanktons aus dem Malm, der Kreide und dem Alttertiär Mitteleuropas. Freiberger Forschungsh., C196:1-109.

Reinhardt, P. and Gorka, H., 1967. Revision of some upper Cretaceous coccoliths from Poland and Germany. Neues Jahrb. Geol. Paläontol. Abh., 129:240-256.

Roth, P. H., 1970. Oligocene calcareous nannoplankton biostratigraphy. Eclog. geol. Helv., 63:799-881.

Roth, P. H., and Thierstein, H. R., 1972. Calcareous nannoplankton: Leg 14 of the Deep Sea Drilling Project. In Hayes, D. E., Pimm, A. C., et al., Init. Repts. DSDP, 14: Washington (U.S. Govt. Printing Office), 421-485.

Ruddiman, W. F., and McIntyre, A., 1979. Warmth of the subpolar North Atlantic Ocean during Northern Hemisphere Ice-sheet Growth. Science, 204:173-175.

Schiller, J., 1930. Coccolithineae. In Rabenhorst, L., KryptogamenFlora von Deutschland, Österreich und der Schweiz, 10: Akad. Verlagsges., Leipzig, 89-267.

Schumenko, S. I., 1968. Some aspects of the ontogenesis, variation and taxonomy of fossil coccolithophorids revealed by electron microscope studies. Paleont. Zhurnal., 4:32-37.

Sissingh, W., 1977. Biostratigraphy of cretaceous calcareous nannoplankton. Geol. Mijnbouw, 56:37-65.

Steinmetz, J. C., 1984a. Bibliography and taxa of calcareous nannoplankton-III. Int. Nannoplankton Assoc. Newsl., 6:6-37.

, 1984b. Bibliography and taxa of calcareous nannoplanktonIV. Int. Nannoplankton Assoc. Newsl., 7:5-28.
1985. Bibliography and taxa of calcareous nannoplanktonV. Int. Nannoplankton Assoc. Newsl., 7:5-28.

Stover, L. E., 1966. Cretaceous coccoliths and associated nannofossils from France and the Netherlands. Micropaleontology, 12:133-167.

Stradner, H., 1961. Vorkommen von Nannofossilien im Mesozoikum und Alttertiär. Erdöl-Z., 77:77-88.

Stradner, H., 1963. New contributions to Mesozoic stratigraphy by means of nannofossils. Proc. World Petrol. Congr., 6th, Sect. 1, Paper 4 (preprint): 1-16.

Stradner, H., and Papp, A., 1961. Tertiäre Discoasteriden aus Österreich und deren stratigraph ische Bedeutung mit Hinweisen auf Mexico, Rumänien und Italien. Jahrb. Geol. Bundesanst. (Wien), Spec. Vol. 7:1-159.

Tan, S. H., 1927. Discoasteridae incertae sedis. Proc. Sect. Sc. K. Akad. Wet. Amsterdam, 30:411-419.

Theodoridis, S., 1984. Calcareous nannofossil biozonation of the Miocene and revision of the helicoliths and discoasters. Netherlands (Loonzetterij Abe, Hoogeveen).

Thierstein, H. R., 1976. Mesozoic calcareous nannoplankton biostratigraphy of marine sediments. Mar. Micropaleontol., 1:325-348, 358362.

Thierstein, H. R., 1981. Late Cretaceous nannoplankton and the change at the Cretaceous-Tertiary Boundary. SEPM Spec. Publ., 32:355394.

Vekshina, V. N., 1959. Coccolithophoridae of the Maastrichtian deposits of the west Siberian lowlands. SNIIGGIMS, 2:56-77.

Wallich, G. C., 1877. Observations on the coccosphere. Ann. Mag. Nat. Hist., Ser. 4, 16:322-339.

Wise, S. W., 1973. Calcareous nannofossils from cores recovered during Leg 18, Deep Sea Drilling Project: biostratigraphy and observations on diagenesis. In Kulm, C. D., Von Huene, R., et al., Init. Repts. $D S D P, 18$ : Washington (U.S. Govt. Printing Office), 569-615.

Ziegler, P. A., 1982. Geological Atlas of Western and Central Europe: The Netherlands (Drukkerij Verweij B. V., Mijdrecht).

Date of initial receipt: 23 March 1987

Date of acceptance: 8 January 1988

Ms 104B-156

\section{APPENDIX}

Taxa Considered in this Report

Acanthoica (Lohmann, 1903) Schiller (1930). Arkhangelskiella cymbiformis Vekshina (1959).

Also included here are: Bronsonia enormis (Schumenko, 1968) Manivit (1971) and its morphotypes.

Biscutum constans (Gorka, 1957) Black (1967).

Braarudosphaera bigelowii (Gran and Braarud, 1935) Deflandre, 1947.

Calcidiscus leptoporus (Murray and Blackman, 1898) Loeblich and Tappan, 1978.

Calcidiscus macintyrei (Bukry and Bramlette, 1969) Loeblich and Tappan (1978).

Chiastozygus litterarius (Gorka, 1957) Manivit (1971).

Coccolithus miopelagicus Bukry (1971).

Coccolithus pelagicus (Wallich, 1877) Schiller (1930).

Cretarhabdus angustiforatus (Black, 1971) Bukry (1973) = Retecapsa angustiforata Black (1971).

Cribrosphaerella ehrenbergii (Arkhangelsky, 1912) Deflandre in Piveteau (1952).

Cyclicargolithus abisectus (Müller, 1970), Wise (1973).

Cyclicargolithus floridanus (Roth and Hay in Hay et al., 1967) Bukry (1971).

Cylindralithus serratus Bramlette and Martini (1964). Also included here is: C. gallicus (Stradner, 1963) Bramlette and Martini (1964).

Dictyococcites Black (1967)

This genus includes the following species: Dictyococcites antarcticus Haq (1976).

Dictyococcites productus (Kamptner, 1963) Backman (1980).

Discocater brouweri Tan (1927).

Discoaster deflandrei Bramlette and Riedel (1954).

Discoaster elegans Bramlette and Sullivan (1961).

Discoaster intercalcaris Bukry (1971).

Discoaster pentaradiatus Tan (1927). 


\section{DONNALLY}

Discoaster surculus Bramlette and Riedel (1954).

Discoaster tamalis Kamptner (1967).

Discoaster variabilis Martini and Bramlette (1963).

Eiffellithus frabeculatus (Gorka, 1957) Reinhardt and Gorka (1967).

Eiffellithus turriseiffeli (Deflandre in Deflandre and Fert, 1954) Reinhardt (1965).

Also included here is: E. eximius (Stover, 1966) Perch-Nielsen (1968).

Emiliania huxleyi (Lohmann, 1902) Hay and Mohler in Hay et al. (1967). This species was observed to have a length of up to $5 \mu \mathrm{m}$ in the top few meters of sediments.

Gephyrocapsa Kamptner (1943).

The following species are included in this genus:

G. aperta Kamptner (1963).

G. ericsonii McIntyre et al. (1967).

G. protohuxleyi McIntyre (1970).

Helicosphaera carteri (Wallich, 1877) Kamptner (1954).

Helicosphaera euphratus Haq (1966).

Helicosphaera intermedia Martini (1965).

Helicosphaera paleocarteri Theodoridis (1984).

Helicosphaera sellii (Bukry and Bramlette, 1969) Jafar and Martini (1975).

Kamptnerius magnificus Deflandre (1959).

Lithraphidites magnificus Bramlette and Martini (1964).

Lucianorhabdulus cayeuxii Deflandre (1959).

Microrhabdulus decoratus Deflandre (1959).

Micula murus (Martini, 1961) Bukry (1973).

Micula staurophora (Gardet, 1955) Stradner (1963).

Nephrolithus frequens Gorka (1957).

Pontosphaera Lohman (1902).

Pontoshaera enormis (Locker, 1967) Perch-Nielsen (1984).
Prediscosphaera cretacea (Arkhangelsky, 1912) Gartner (1968).

Pseudoemiliania lacunosa (Kamptner, 1963) Gartner (1969).

Reticulofenestra Hay, Mohler, and Wade (1966). The following species are included in this genus:

Reticulofenestra haqii Backman (1978).

Reticulofenestra minuta Roth (1970).

Reticulofenestra minutula (Gartner, 1967) Haq and Berggren (1978).

Reticulofenestra pseudoumbilica (Gartner, 1967) Gartner (1969).

Rhabdosphaera Haeckel (1894).

Sphenolithus moriformis (Brönnimann and Stradner, 1960) Bramlette and Wilcoxon (1967).

Included with this taxon are:

S. abies Deflandre in Deflandre and Fert (1954).

$S$. neoabies Bukry and Bramlette (1969).

Syracosphaera Lohmann (1902).

Tetralithus aculeus (Stradner, 1961) Gartner $(1968)=$ Ceratolithoides aculeus (Stradner, 1961) Prins and Sissingh in Sissingh (1977).

Tetralithus obscurus Stradner (1963) = Calculites obscurus (Deflandre, 1959) Prins and Sissingh in Sissingh (1977).

Tetralithus trifidus (Stradner, 1961) Bukry (1973) = Quadrum trifidum (Stradner in Stadner and Papp, 1961) Prins and Perch-Nielsen in Manivit et al. (1977).

Thoracosphaera Kamptner (1927).

Tranolithus orionatus (Reinhardt, 1966) Perch-Nielsen $(1968)=T$. phacelosus Stover (1966).

Valgalapilla octoradiata (Gorka, 1957) Bukry (1969).

Watznaueria barnesae (Black in Black and Barnes, 1953) Perch-Nielsen (1968).

Zygodiscus diplogrammus (Deflandre, 1954) Gartner $(1968)=$ Glaukolithus diplogrammus Reinhardt (1964). 


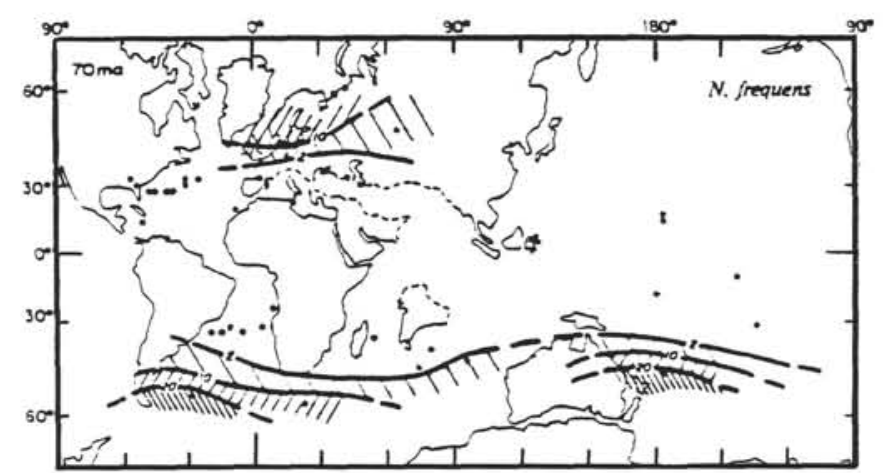

Averaged percent abundance of Nephrolithus frequens in the 118 latest Maastrichtian assemblages investigated.

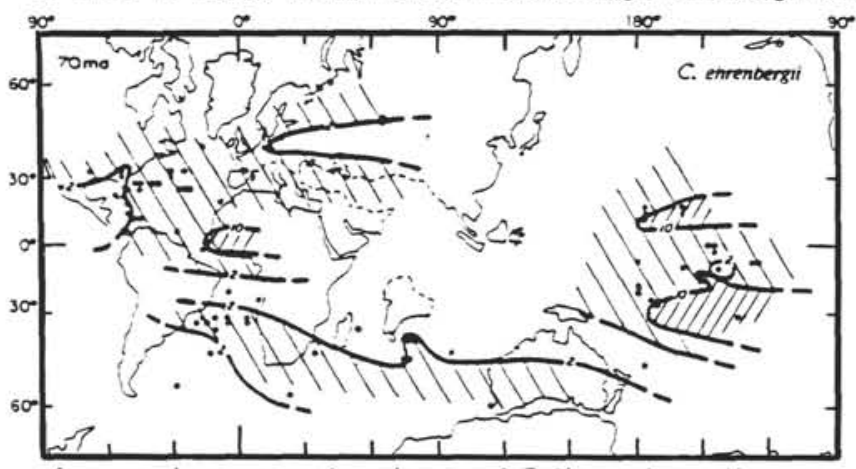

Averaged percent abundance of Cribrosphaerella ehrenbergii in the late Campanian through latest Maastrichtian assemblages investigated.

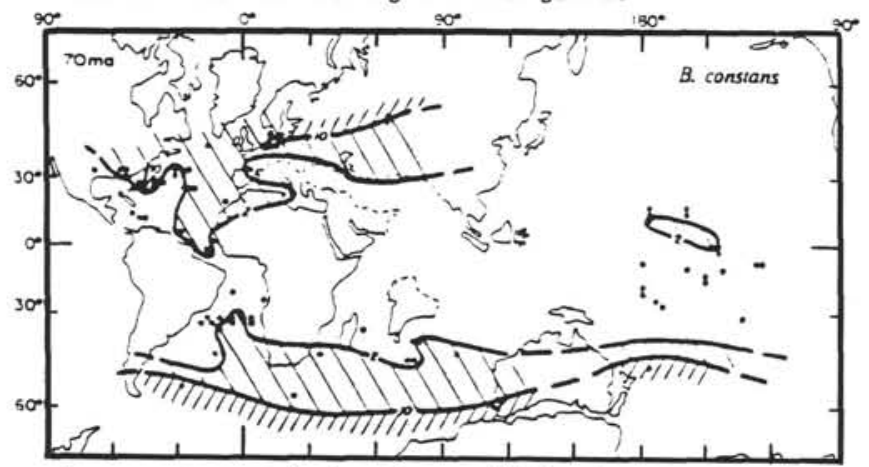

Averaged percent abundance of Biscutum constans in the 243 late Campanian through latest Maastrichtian assemblages investigated.

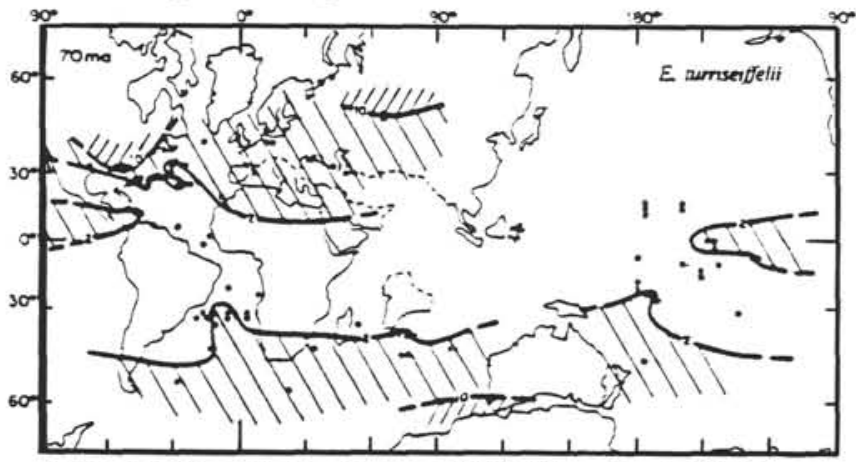

Averaged percent abundance of Eiffellithus turriseiffeli in the 243 late Campanian through latest Maas trichtian ass e mblages investigated.

Figure 5. Geographic distribution of selected taxa actually encountered in Leg 104 glacial sediments (Thierstein, 1981).

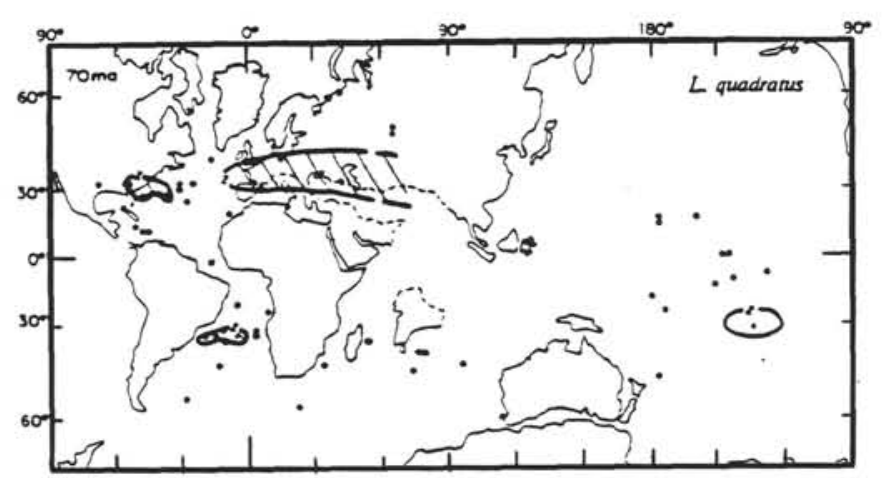

Averaged percent abundance of Lithraphidites quadratus in the 189 middle to latest Maastrichtian assemblages investigated.

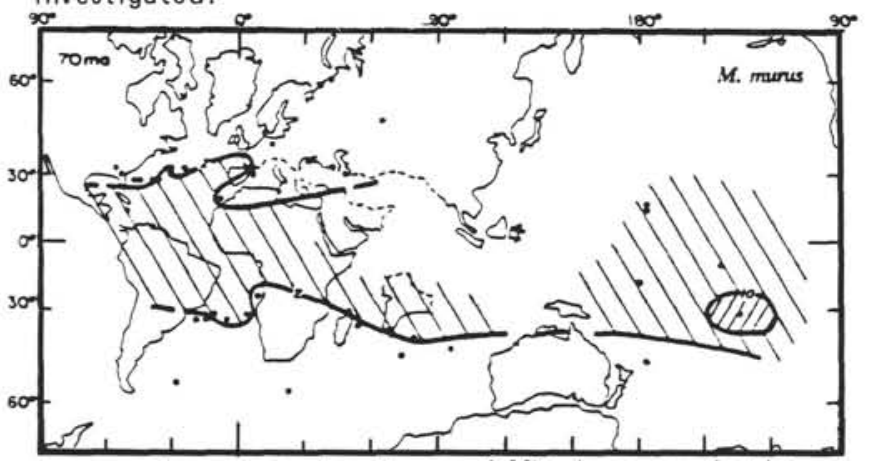

Averaged percent abundance of Micula murus in the 118 latest Maastrichtian assemblages investigated.

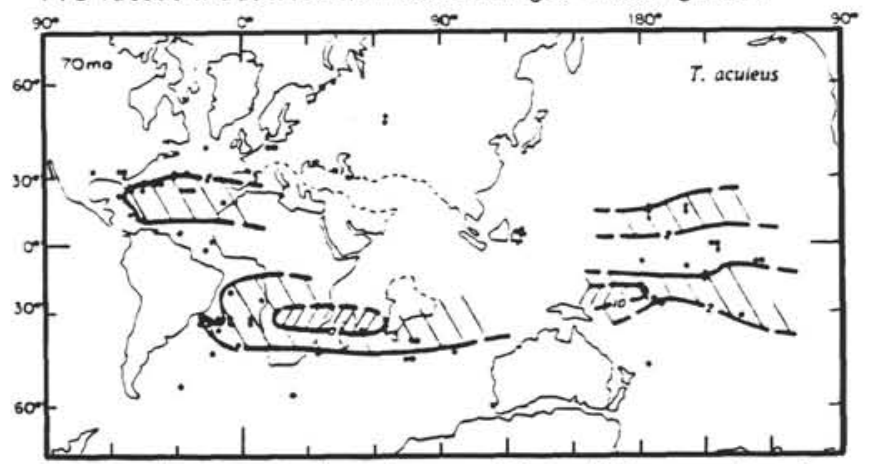

Averaged percent abundance of Tetralithus aculeus in the 243 late Campanian through latest Maastrichtian assemblages investigated.

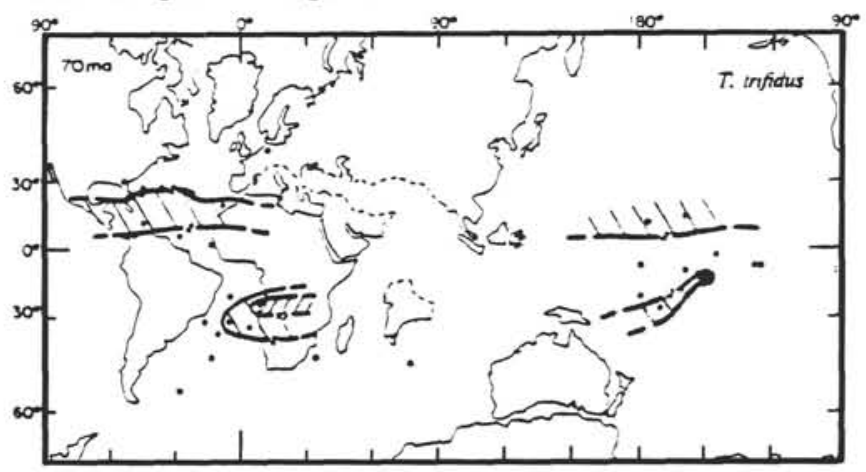

Averaged percent abundance of Tetralithus trifidus in the 54 late Campanian to earliest Maastrichtian assemblages investigated.

Figure 6. Geographic distribution of selected taxa (studied by Thierstein, 1981) not encountered in ODP Leg 104 glacial sediments. 


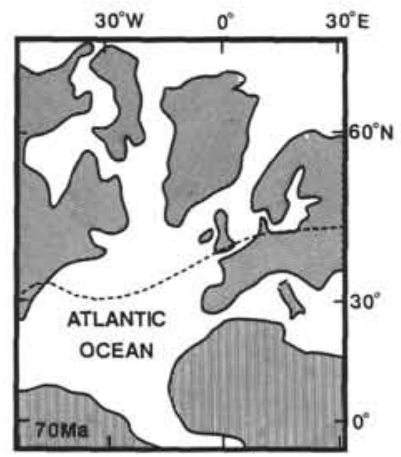

Figure 7. Summary of the northern limits of geographic occurrences (Fig. 6) of various Cretaceous nannofossils not found on Leg 104 (based on Thierstein, 1981). The source of the reworked nannofossils is north of the dashed line.
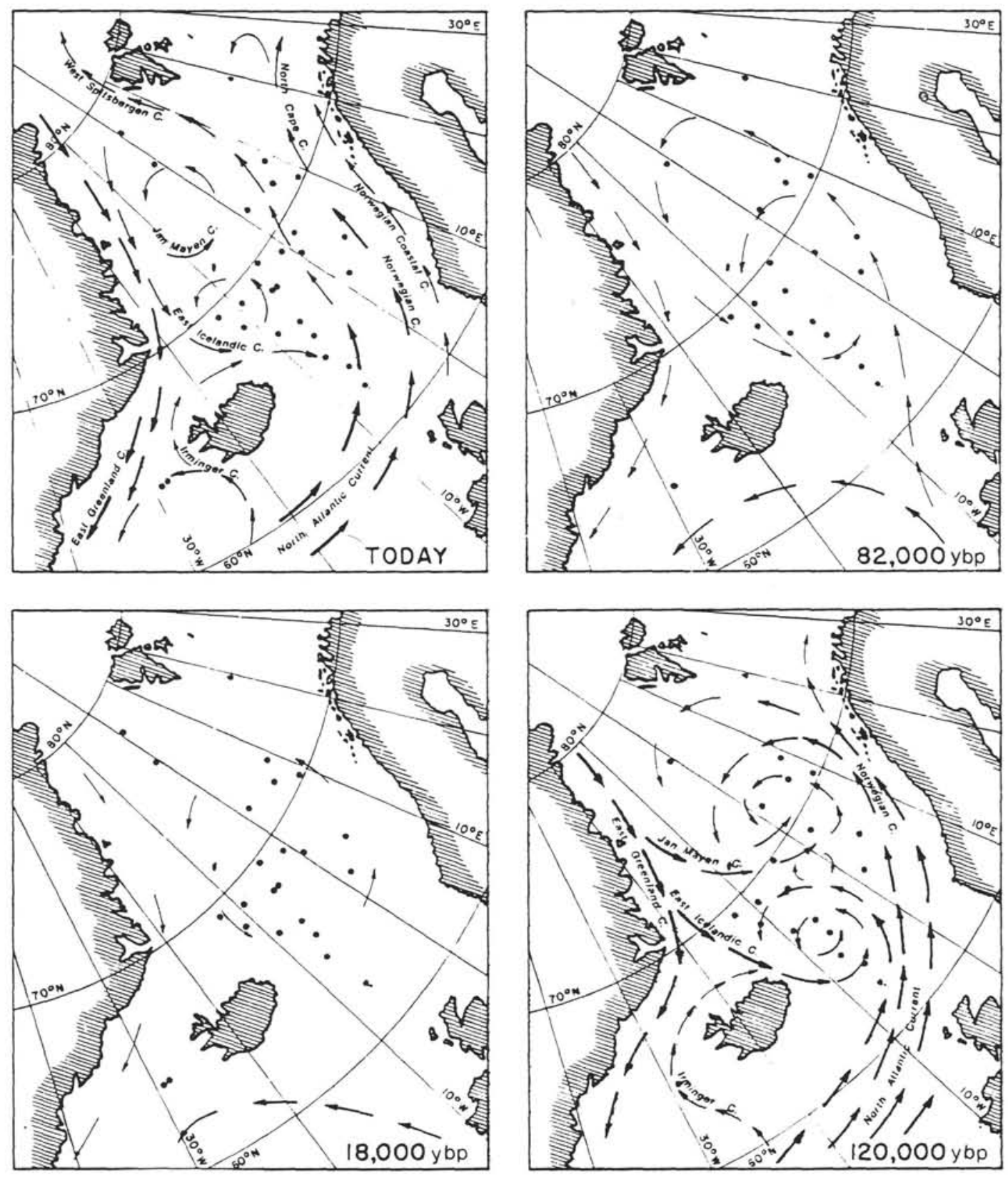

Figure 9. Sea-surface reconstructions for today, 18,000-, 82,000-, and 120,000-y.b.p. levels (from Kellogg, 1980).
Figure 8. Summary of the southern limits of the geographic distributions (Fig. 5) of various reworked Cretaceous nannofossils (with abundance greater than 2\%) found in Leg 104 sediments (based on Thierstein, 1981). The source for the reworked nannofossils is north of the dashed line.

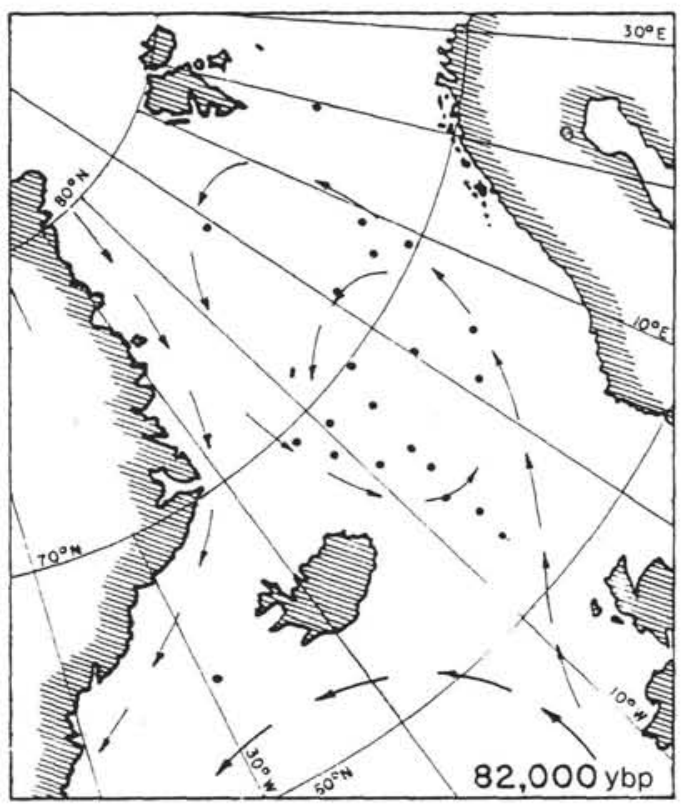



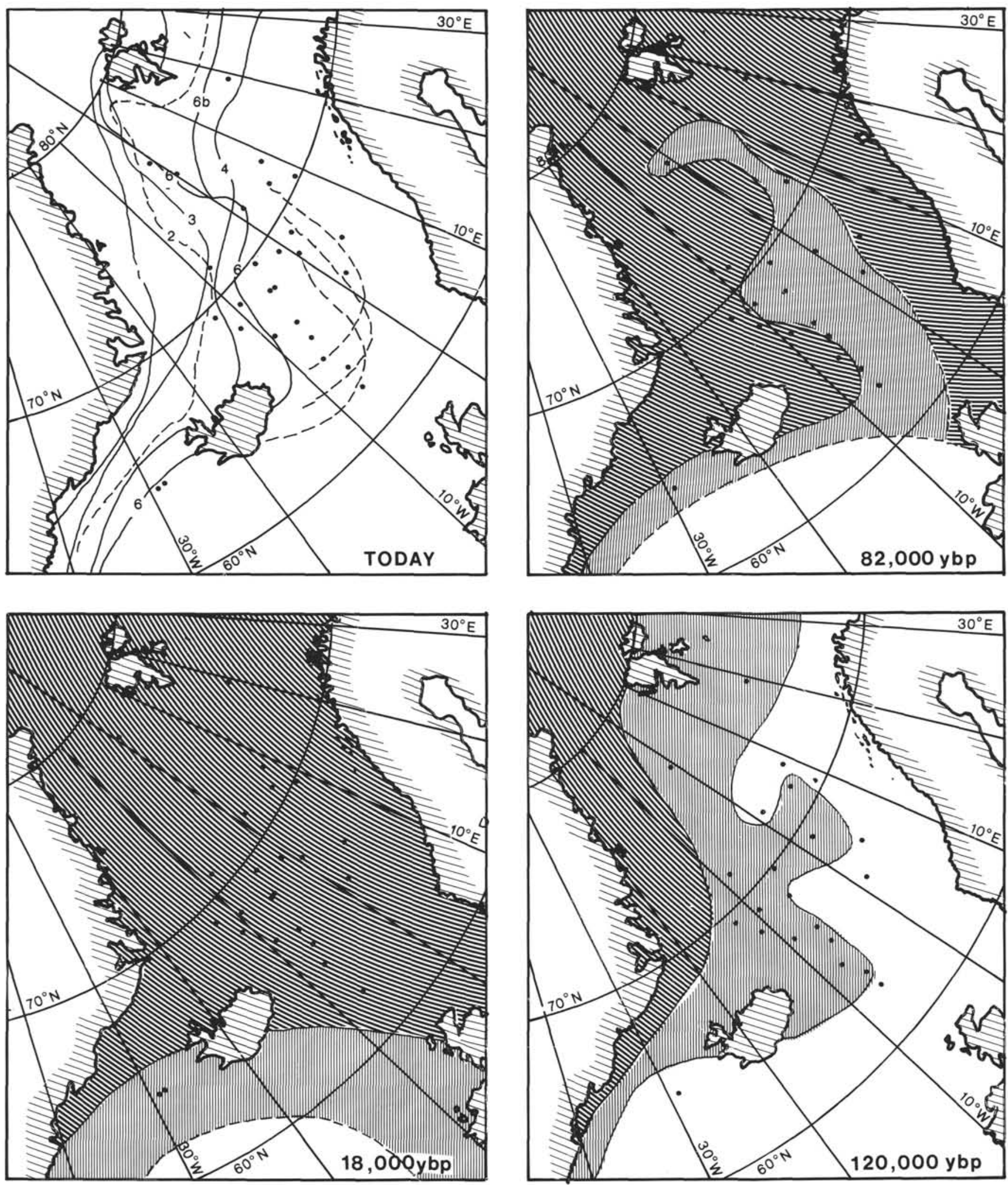

Figure 10. Sea-ice reconstructions for today, 18,000, 82,000, and 120,000-y.b.p. levels (from Kellogg, 1980). Darker pattern: permanent ice, lighter pattern: seasonal ice. 


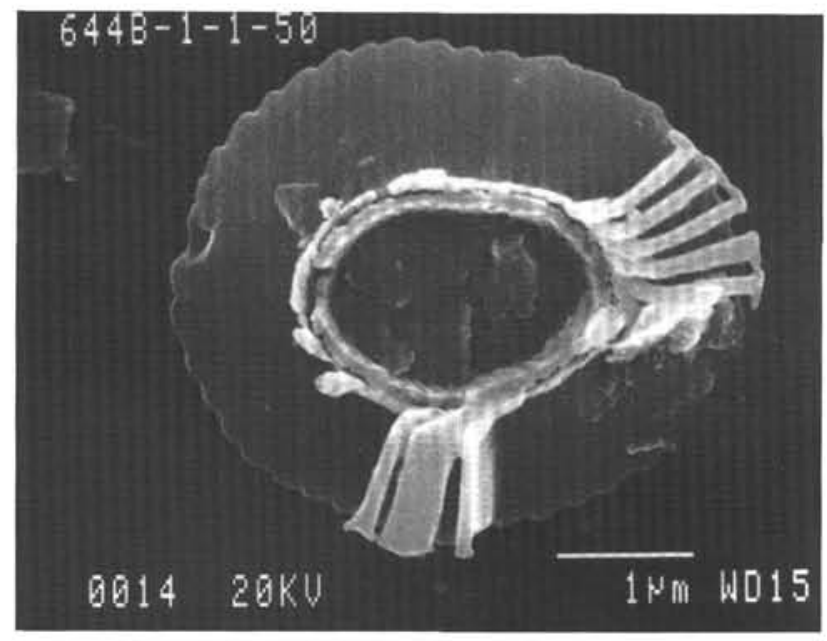

1

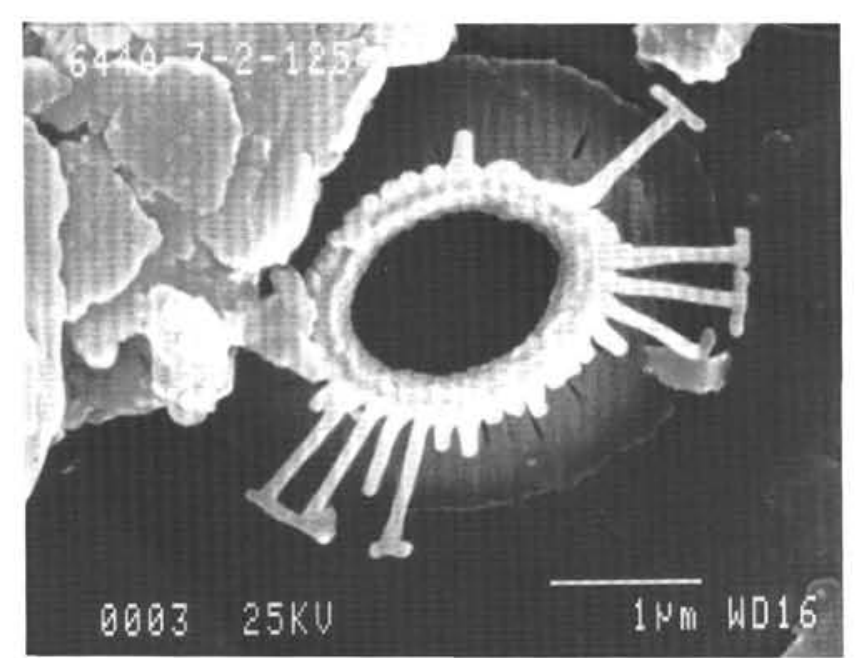

3

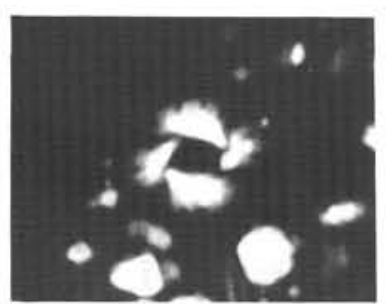

$5 a$

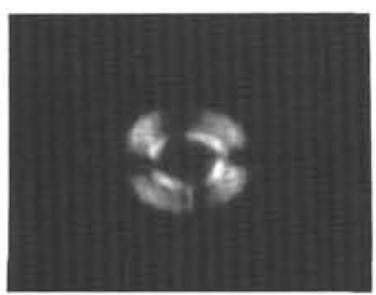

$2 a$

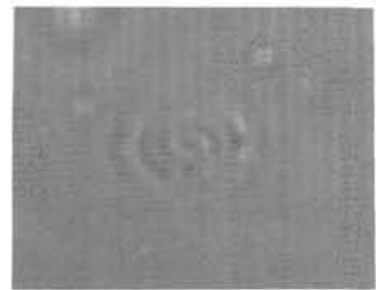

2c

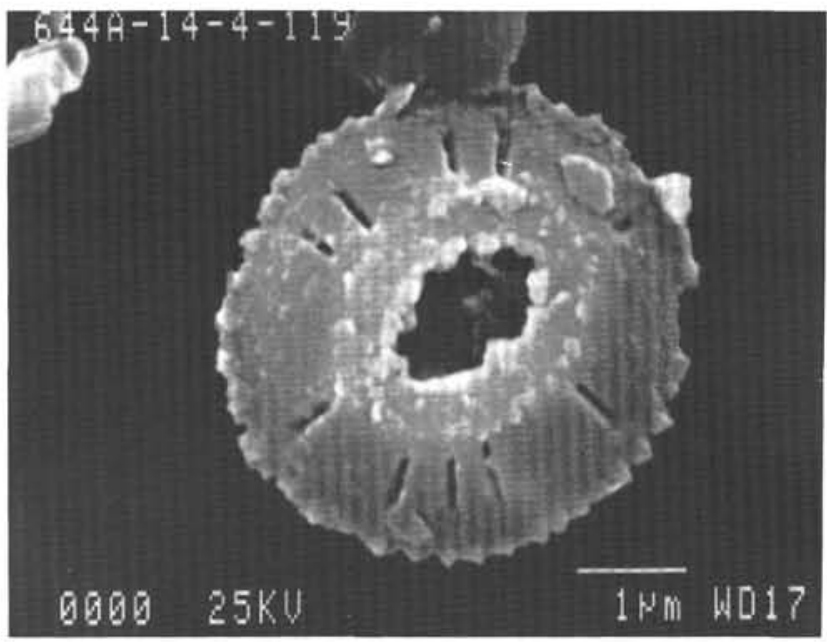

4

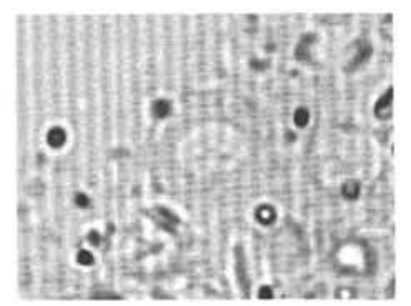

$5 c$

Plate 1. 1. Emiliania huxleyi, 104-644B-1-1, $50 \mathrm{~cm}, 4-5 \mu \mathrm{m}$. 2. Same specimen as (1); (2a) x-p, (2b) ph, (2c) tr lt. 3. Emiliania huxleyi, 104$644 \mathrm{~A}-3-2,125 \mathrm{~cm}, 4 \mu \mathrm{m}$. 4. Pseudoemiliana lacunosa, 104-644A-14-4, $119 \mathrm{~cm}, 4.5 \mu \mathrm{m}$. 5. Pseudoemiliana lacunosa, 104-644A-10-5, $50 \mathrm{~cm}, 5 \mu \mathrm{m}$; (5a) $\mathrm{x}-\mathrm{p},(5 \mathrm{~b}) \mathrm{ph},(5 \mathrm{c}) \mathrm{tr}$ lt. 


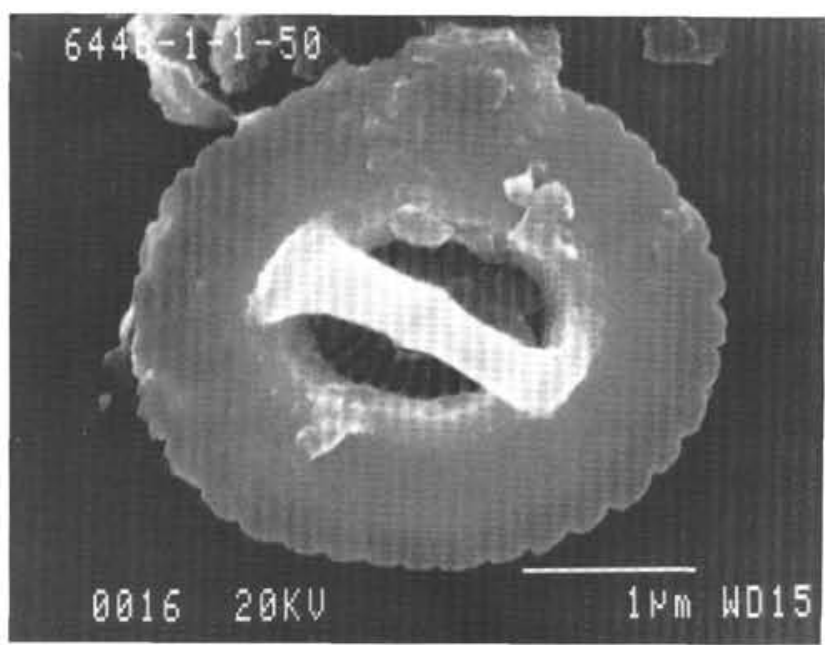

1

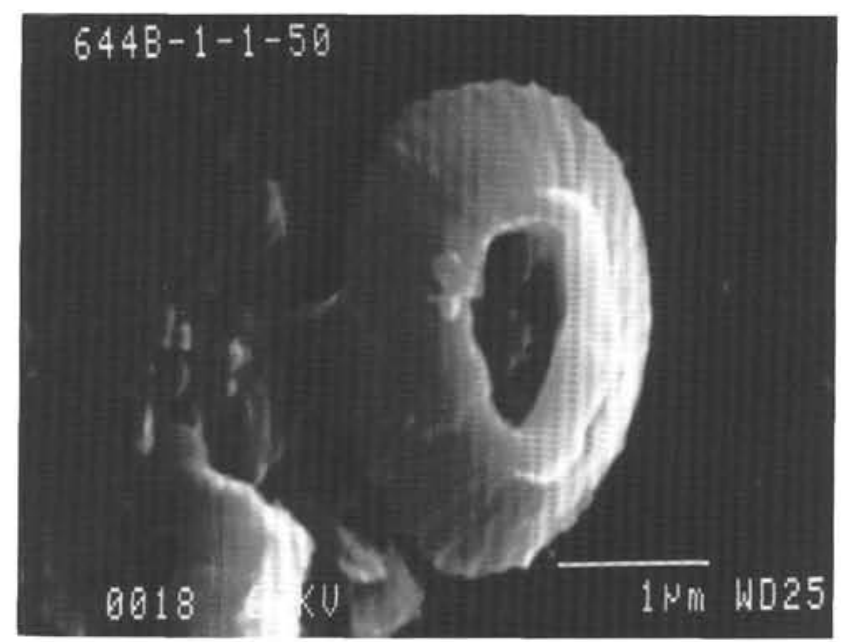

3

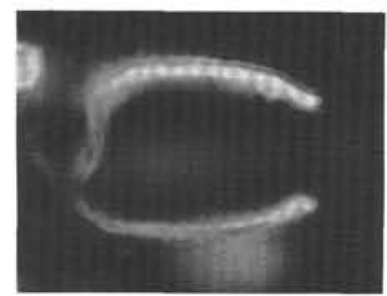

$5 a$

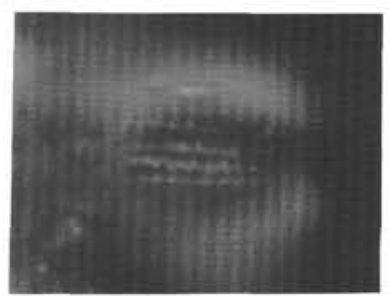

$5 \mathbf{b}$

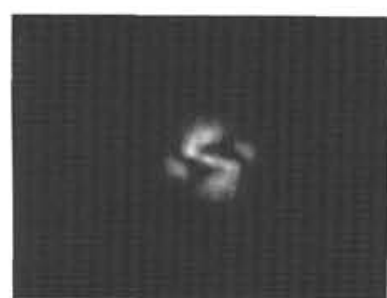

2 a

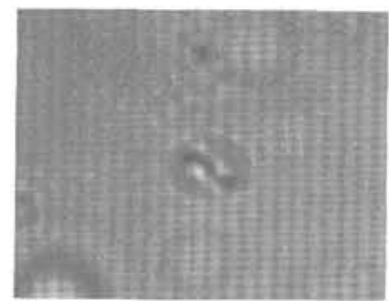

2c

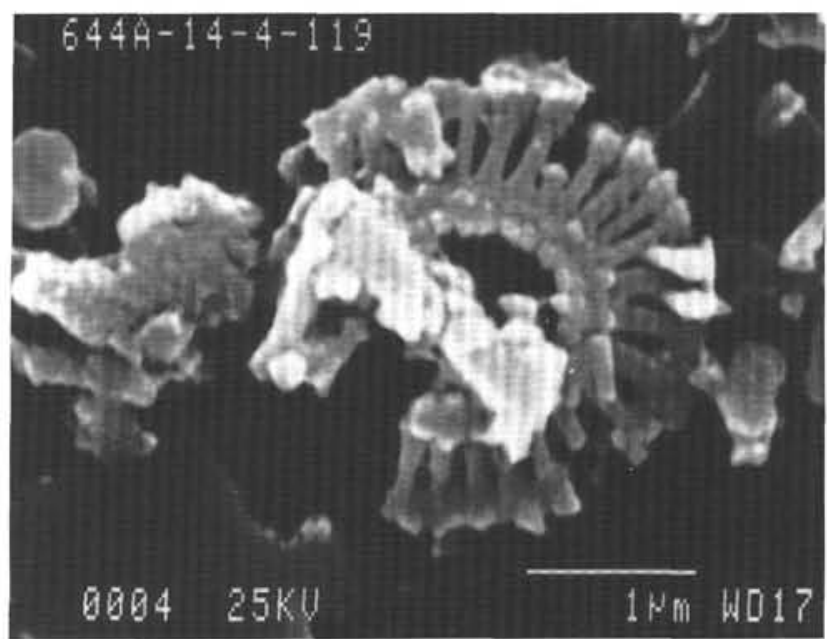

4

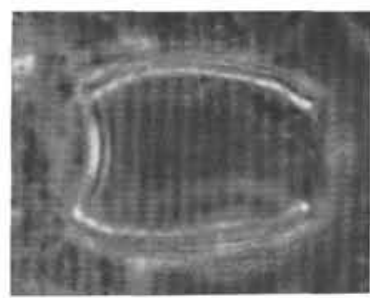

$5 c$

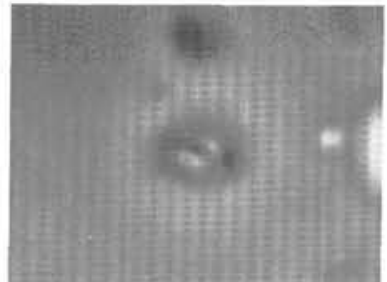

$2 b$

Plate 2. 1. Gephyrocapsa sp., 104-644B-1-1, $50 \mathrm{~cm}, 3.5 \mu \mathrm{m}$. 2. Same specimen as (1); (2a) x-p, (2b) ph, (2c) tr lt. 3. Same specimen as (1); tilted $35^{\circ}$. 4. Gephyrocapsa protohuxleyi, 104-644A-14-4, $119 \mathrm{~cm}, 3 \mu \mathrm{m}$. 5. Syracosphaera sp., 104-644A-33-1, $50 \mathrm{~cm}, 15 \mu \mathrm{m}$. (5a) x-p, (5b) ph, (5c) tr lt. 


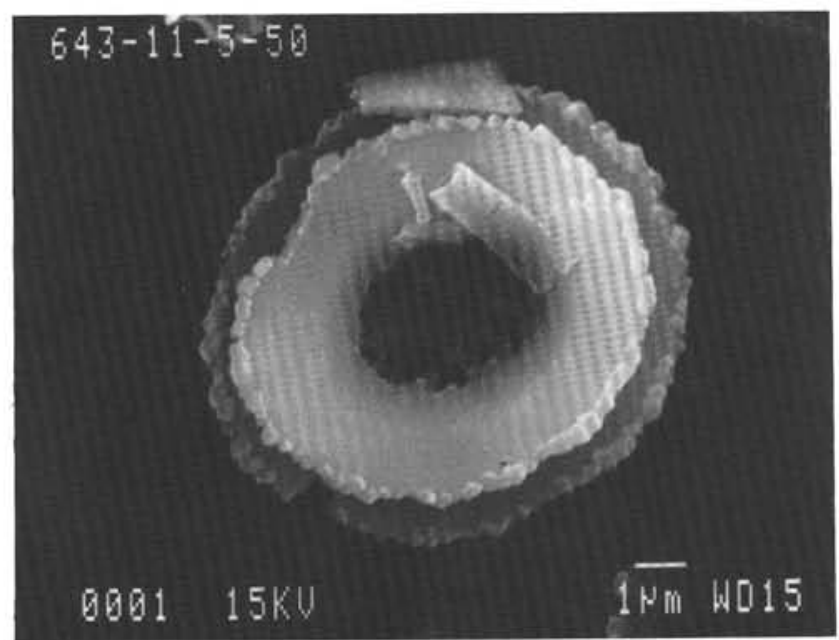

1

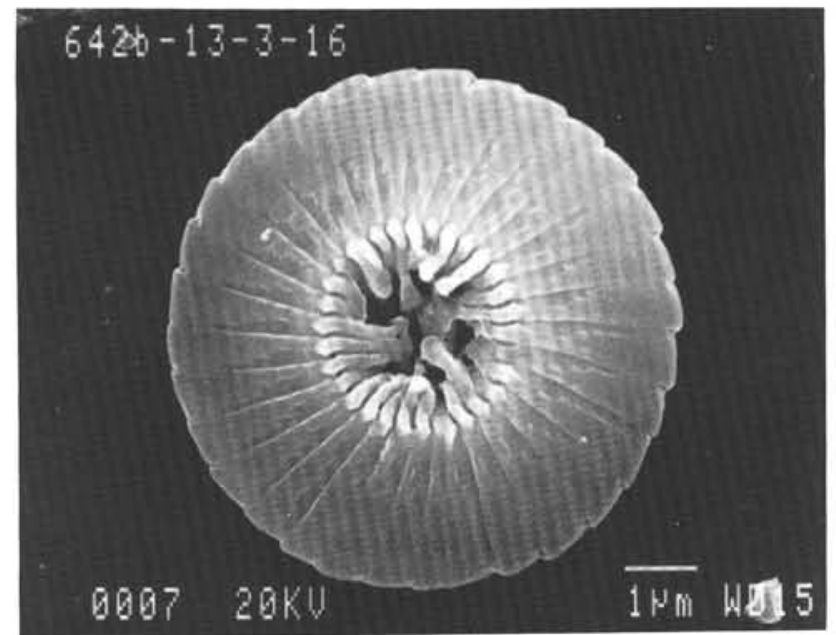

3

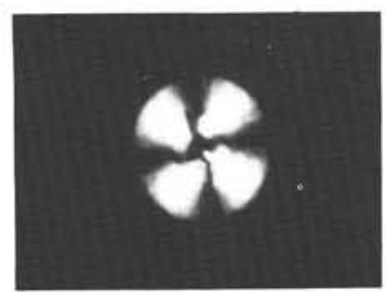

$4 a$

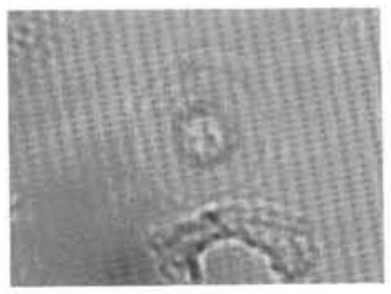

$4 b$

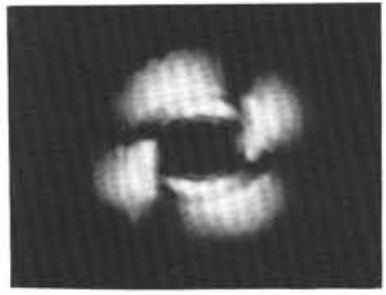

$2 a$

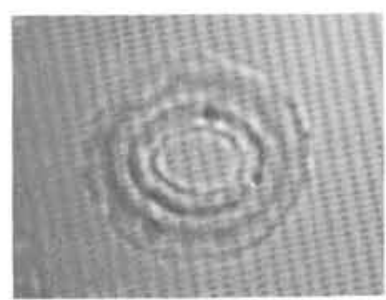

2c

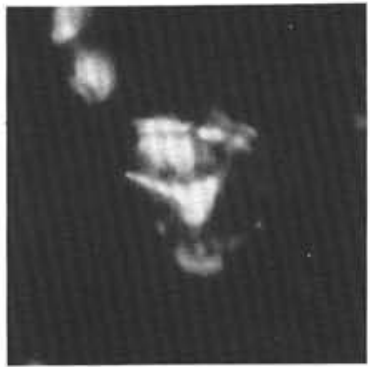

$5 a$

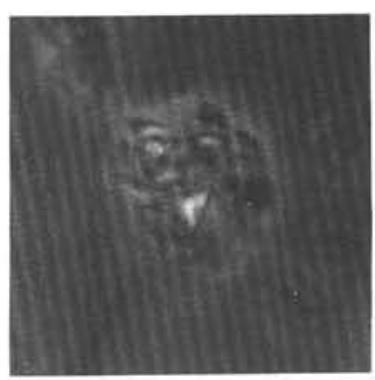

$5 b$

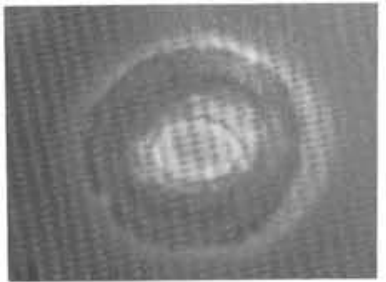

$2 b$

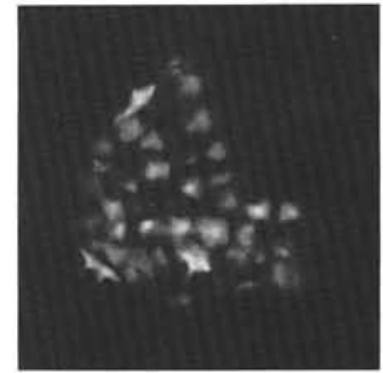

$6 a$

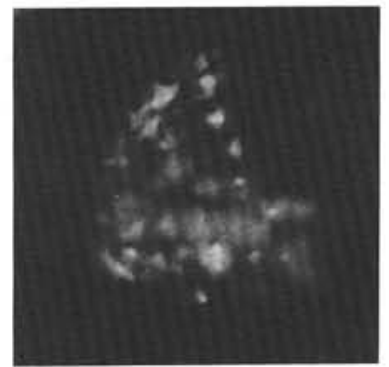

6b

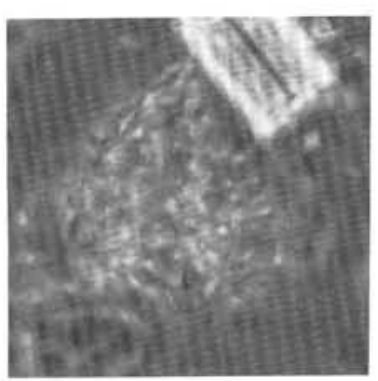

6c

Plate 3. 1. Reticulofenestra pseudoumbilica, 104-643A-11-5, $50 \mathrm{~cm}, 10 \mu \mathrm{m}$. 2. Same specimen as (1); (2a) $\mathrm{x}-\mathrm{p},(2 \mathrm{~b}) \mathrm{ph},(2 \mathrm{c}) \mathrm{tr} \mathrm{lt}$. 3. Calcidiscus leptoporus, 104-642B-13-3, $16 \mu \mathrm{m}, 7 \mu \mathrm{m}$. 4. Same specimen as (3); (4a) x-p, (4b) tr lt. 5. Acanthoica sp., 104-644B-10-2, 96 cm, $5 \mu \mathrm{m}$. (5a) x-p, (5b) ph. 6. Acanthoica spp. cluster, 104-644A-19-3, $123 \mathrm{~cm}, 20 \mu \mathrm{m}$. (6a) x-p, high focus (6b) x-p, low focus (6c) ph. 


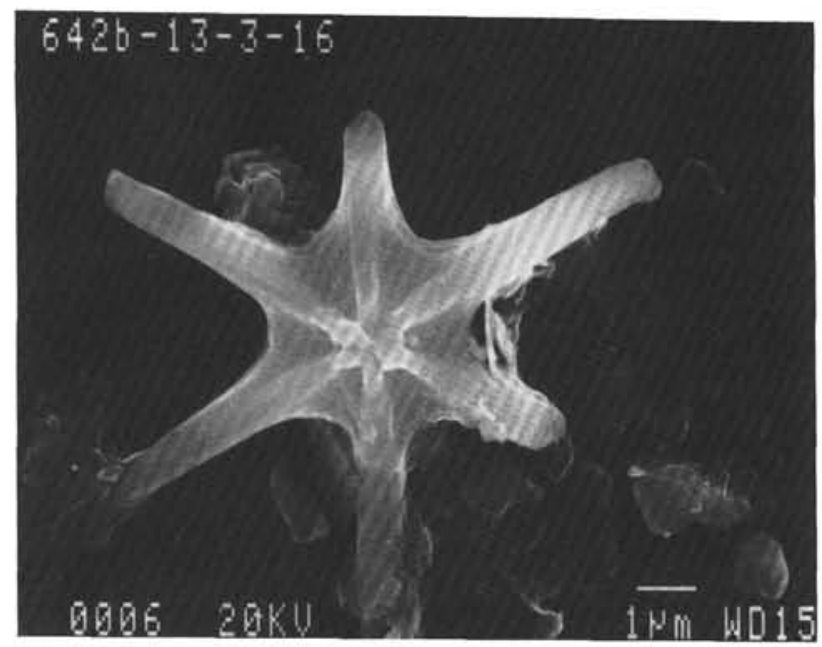

1

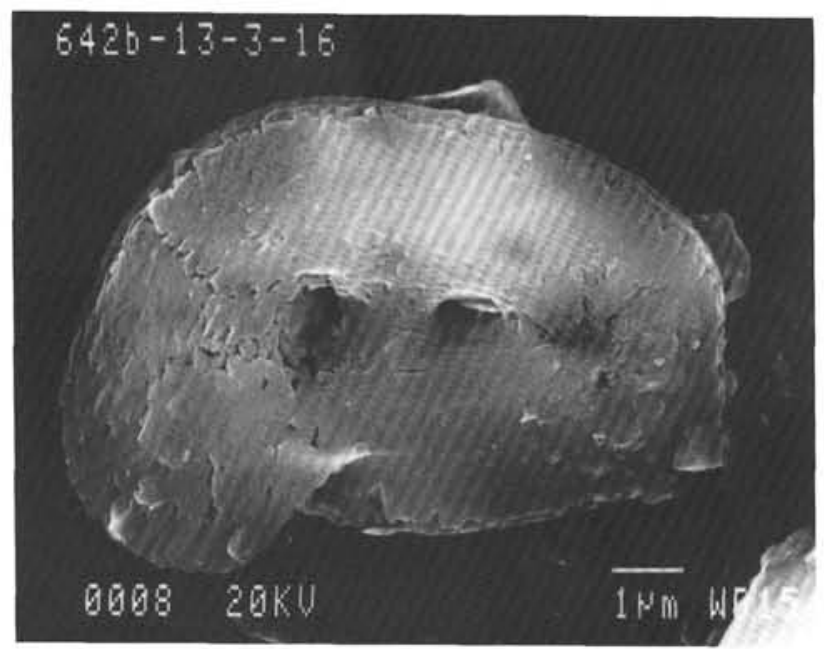

3

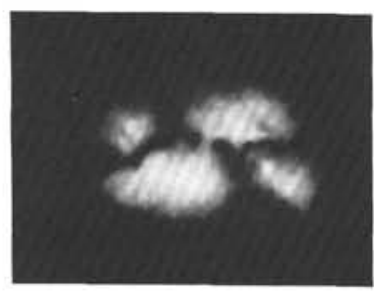

$5 \mathbf{a}$

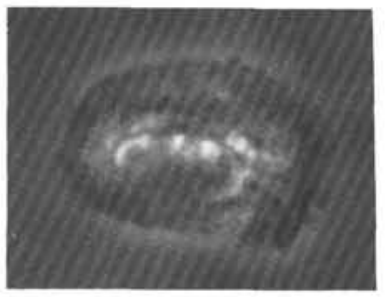

5b

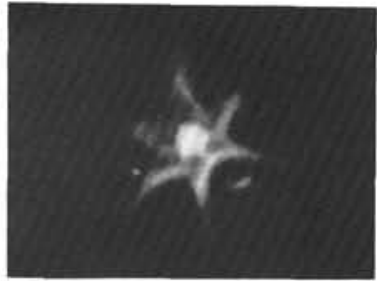

$2 a$

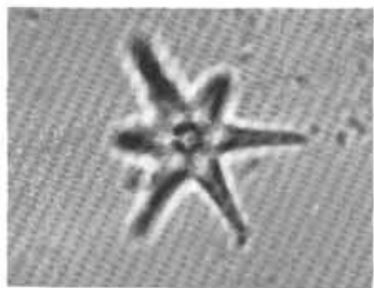

2c

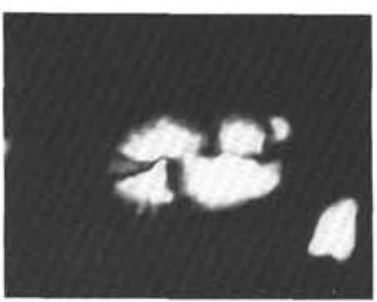

$4 a$

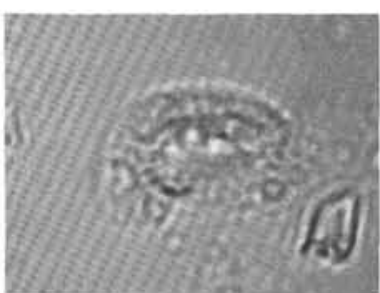

$4 c$

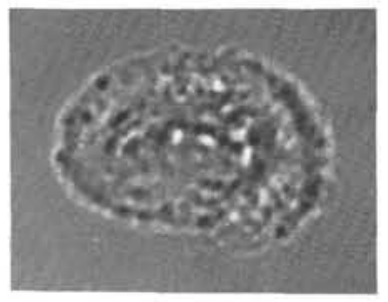

$5 \mathrm{c}$

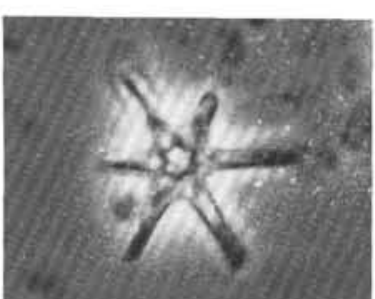

$2 b$

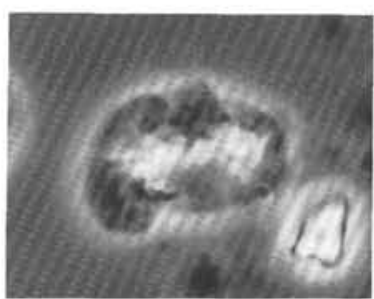

$4 b$

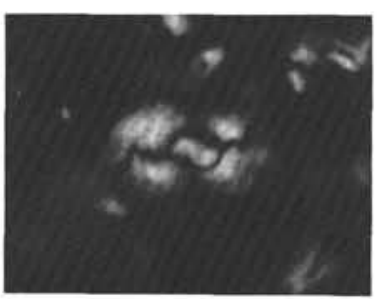

6

Plate 4. 1. Discoaster intercalcaris 104-642B-13-3, $16 \mathrm{~cm}, 10.5 \mu \mathrm{m}$. 2. Same specimen as (1); (2a) $\mathrm{x}-\mathrm{p},(2 \mathrm{~b}) \mathrm{ph},(2 \mathrm{c}) \mathrm{tr}$ lt. 3. Helicosphaera carteri, 104-642B-13-3, $16 \mathrm{~cm}, 9 \mu \mathrm{m}$. 4. Same specimen as (3); (4a) x-p, (4b) ph, (4c) tr lt. $\quad$ 5. Helicosphaera sellii, 104-642B-13-1, 101 cm, 12 $\mu \mathrm{m}$. (5a) $\mathrm{x}-\mathrm{p},(5 \mathrm{~b}) \mathrm{ph},(5 \mathrm{c})$ tr lt. 6. Helicosphaera euphratis, 104-643A-43-CC, $10 \mu \mathrm{m}$, x-p. 


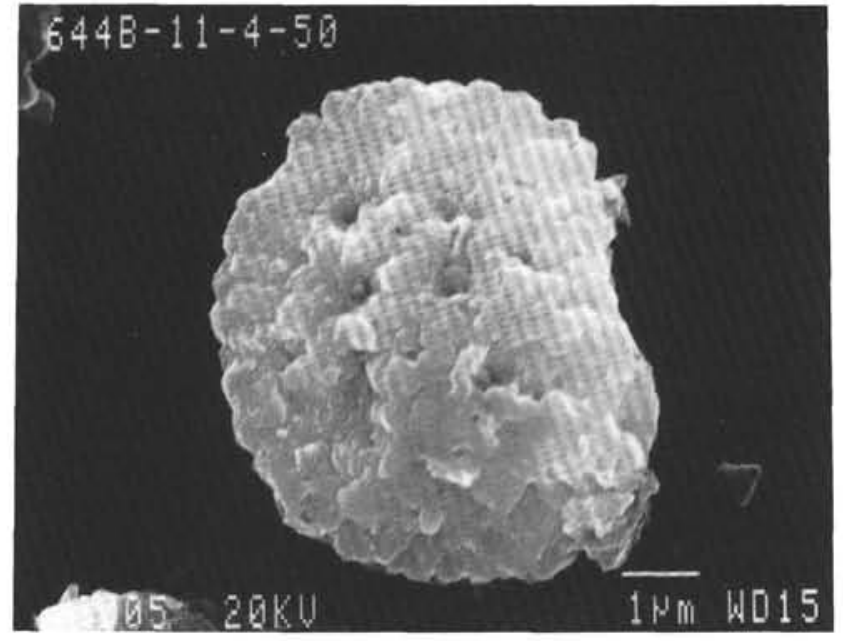

1

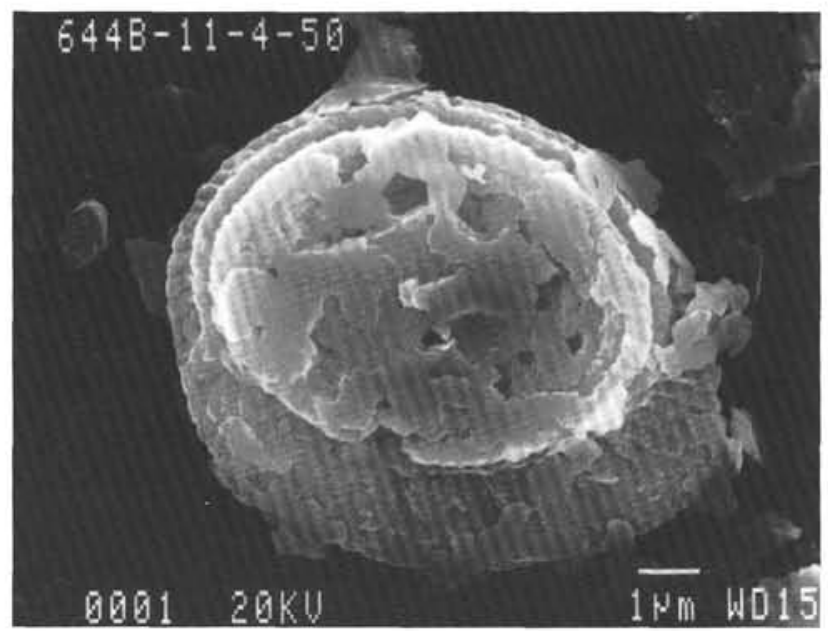

3

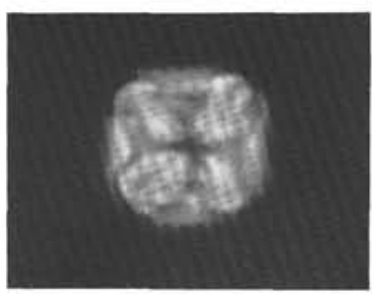

$6 a$

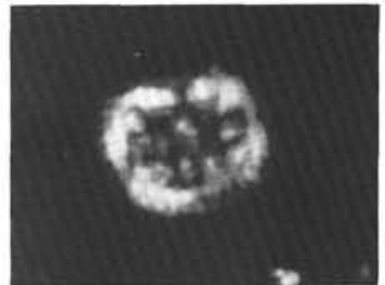

2a

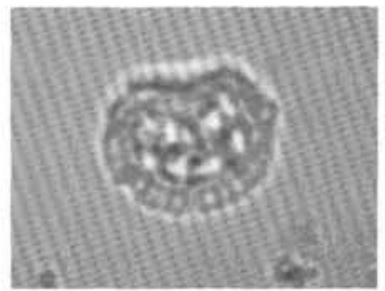

2c

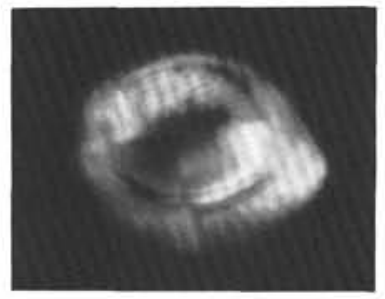

$4 a$

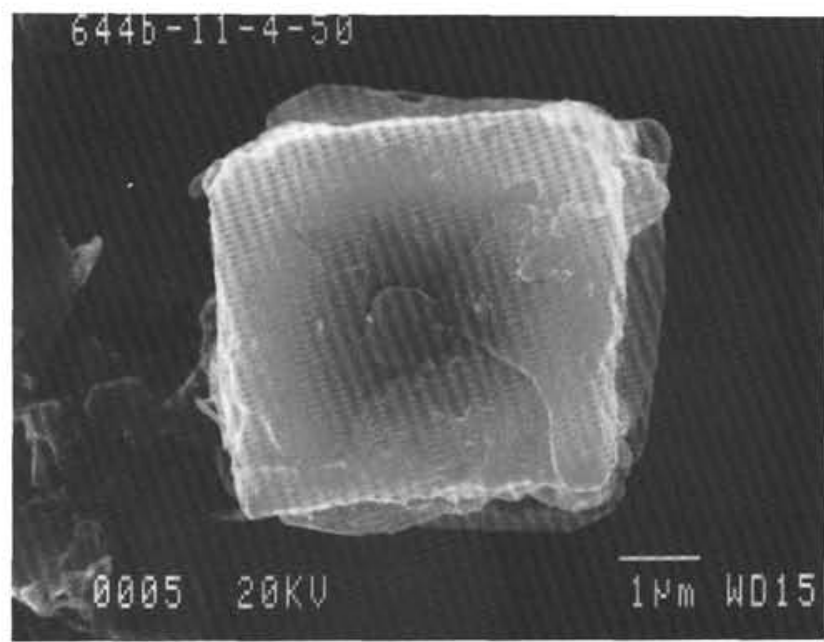

5

Plate 5. 1. Nephrolithus frequens, $104-644 \mathrm{~b}-11-4,50 \mathrm{~cm}, 6 \mu \mathrm{m}$. 2. Same specimen as (1); (2a) $\mathrm{x}-\mathrm{p},(2 \mathrm{~b}) \mathrm{ph},(2 \mathrm{c}) \mathrm{tr}$ lt. 3. Kamptnerius magnificus, 104-644B-11-4, $50 \mathrm{~cm}, 10 \mu \mathrm{m}$. 4. Same specimen as (3); (4a) x-p, (4b) ph, (4c) tr lt. 5. Micula staurophora, 104-644B-11-4, 50 cm, $5 \mu \mathrm{m}$. 6. Same specimen as (5); (6a) x-p, (6b) ph. 